\title{
A latest Biharian small vertebrate fauna from the lacustrine succession of San Lorenzo (Sant'Arcangelo Basin, Basilicata, Italy)
}

\author{
Federico Masini $^{\mathrm{a}, *}$, Tessa Giannini ${ }^{\mathrm{b}}$, Laura Abbazzi ${ }^{\mathrm{b}}$, Flaviano Fanfani ${ }^{\mathrm{b}}$, \\ Massimo Delfino ${ }^{\mathrm{b}}$, Lutz Christian Maul ${ }^{\mathrm{c}}$, Danilo Torre ${ }^{\mathrm{b}}$ \\ ${ }^{a}$ Dipartimento di Geologia e Geodesia, Università di Palermo, C.so Tukory 131, I-90134 Palermo, Italy \\ ${ }^{\mathrm{b}}$ Dipartimento di Scienze della Terra e Museo di Storia Naturale (sez. Geo-Paleontologica), Università di Firenze, \\ Via G. La Pira 4, I-50121 Firenze, Italy \\ ${ }^{\mathrm{c}}$ Forschungsinstitut Senckenberg, Forschungsstation für Quartärpaläontologie, Steubenstraße 19a, D-99423 Weimar, Germany
}

Available online 10 December 2004

\begin{abstract}
The Sant'Arcangelo Basin is located in the southern part of the Apennine chain (Basilicata). It is filled by a siliciclastic sequence $3500 \mathrm{~m}$ thick, dated to the Late Pliocene-Middle Pleistocene time interval. In this basin an Early Middle Pleistocene fluvio-lacustrine sequence, known as San Lorenzo Cycle, has been recognised. In the upper part of the sequence, in Rifreddo, a fairly diversified small vertebrate assemblage has been recovered.

The occurrence of Mimomys savini allows to the fauna to be considered as Biharian. The presence of some faunal elements such as Microtus (Terricola) arvalidens, Microtus (Iberomys) ex gr. huescarensis-brecciensis, and Macroneomys cf. brachygnathus restricts the age of the Rifreddo assemblage to the latest part of this Mammal Age. In several European localities, sediments containing such late Biharian faunas are correlated with the lower part of Brunhes magnetochrone (e.g. the normally magnetised sections at West Runton in the United Kingdom, Voigtstedt in Germany and Přezletice in the Czech Republic) or just below this boundary (e.g. the negatively magnetised part of the Atapuerca section-levels TD4-6 in Spain). Taking into account the faunal composition and the positive magnetisation of the sediments outcropping at the Rifreddo locality, the chronological referral of the mammal assemblage can be restricted to the early Brunhes and therefore to the early middle part of Middle Pleistocene.
\end{abstract}

(C) 2004 Elsevier Ltd and INQUA. All rights reserved.

Keywords: Vertebrates; Late Biharian; Middle Pleistocene; Italy

\section{Introduction}

The Sant'Arcangelo basin is located in the southern part of the Apennine chain (Basilicata, Fig. 1). It is filled by a siliciclastic sequence $3500 \mathrm{~m}$ thick, dated to the Late Pliocene-Middle Pleistocene time interval (Pieri et al., 1996; Sabato, 1998; Sabato et al., 2000). In this basin, an Early Middle Pleistocene fluvio-lacustrine sequence (the

\footnotetext{
*Corresponding author.

E-mail addresses: fmasini@unipa.it (F. Masini), paleovert@geo.unifi.it (T. Giannini), paleovert@geo.unifi.it (L. Abbazzi), paleovert@geo.unifi.it (F. Fanfani), paleovert@geo.unifi.it (M. Delfino),maul@fossi.uni-weimar.de (L. Christian Maul), paleovert@geo.unifi.it (D. Torre).
}

San Lorenzo Cycle) has been recognised (Pieri et al., 1996; Sabato, 1998). Two lacustrine successions have been described (Sabato, 1998): the former, $200 \mathrm{~m}$ thick, is located in the depocentral sector of the lake basin (site Serre, marked "a" in Fig. 1) and the latter, $60 \mathrm{~m}$ thick, outcrops in an NNS position along the cutting of the Rifreddo stream in the marginal part of the basin (" $b$ " in Fig. 1).

In the upper part of the second succession, a short sequence of alternating thin coal and volcanoclastic beds is exposed (Sabato, 1998). The organic-rich levels contain fishes, amphibians, reptiles, and a fairly diversified micro-mammal assemblage. A preliminary report on the vertebrate assemblage collected within a 
(A)
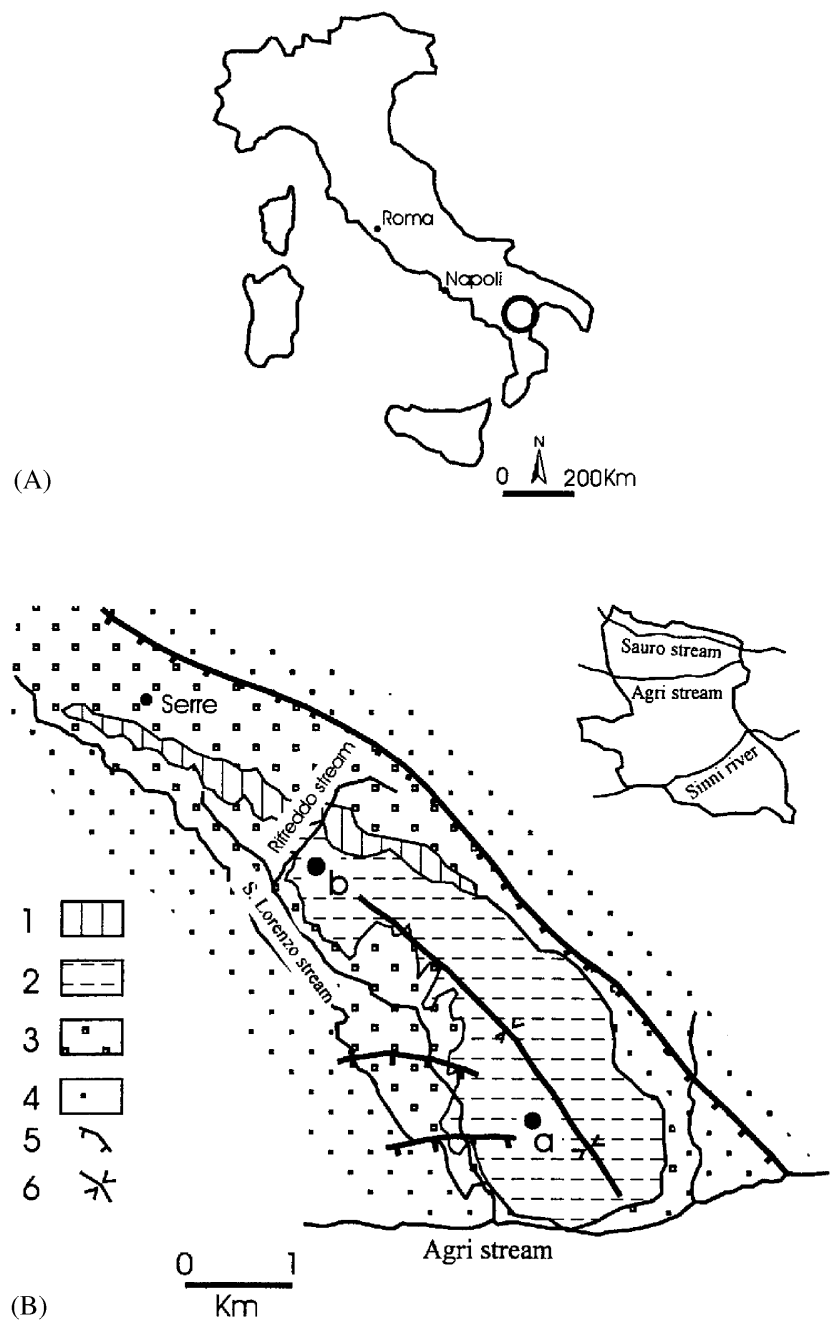

Fig. 1. Location map of the Sant'Arcangelo Basin and of the Rifreddo outcrop (from Caggianelli et al., 1992, modified). 1: conglomeraticsandy upper unit (Early Pleistocene); 2: clayey lacustrine unit (Early-Middle Pleistocene); 3: conglomeratic basal unit (Late Pliocene-Early Pleistocene); $4=$ marine sands (Late Pliocene); $5=$ normal fault; $6=$ syncline; $a=$ Serre site; $b=$ Rifreddo site.

single layer at the Rifreddo site has been communicated by Sabato et al. (1998). During a new field investigation in 1998, two further fossiliferous peat layers have been identified and sampled. The positions of the samples, which have been screen sieved for the collecting of fossil material, are indicated in Fig. 2.

The lower level, $0.4 \mathrm{~m}$ thick, lies on a sandy unit and is overlain by a continuous volcaniclastic horizon (tephra), $0.5 \mathrm{~m}$ thick. This organic level bears a rich assemblage of freshwater gastropods, fish otolithes and vertebrate remains. The second, middle, organic level, $0.4 \mathrm{~m}$ thick, is represented by peaty-clay, bearing carbon remains, molluscs, fish otolithes and fragmental vertebrate bones. It overlies a $0.2 \mathrm{~m}$ thick level of clay and it is covered by a grey clayey horizon intercalated by a thin $(0.1 \mathrm{~m}$ thick $)$ volcaniclastic layer. The uppermost peaty-clayey level, $0.35 \mathrm{~m}$ thick, is also rich in vegetational remains and

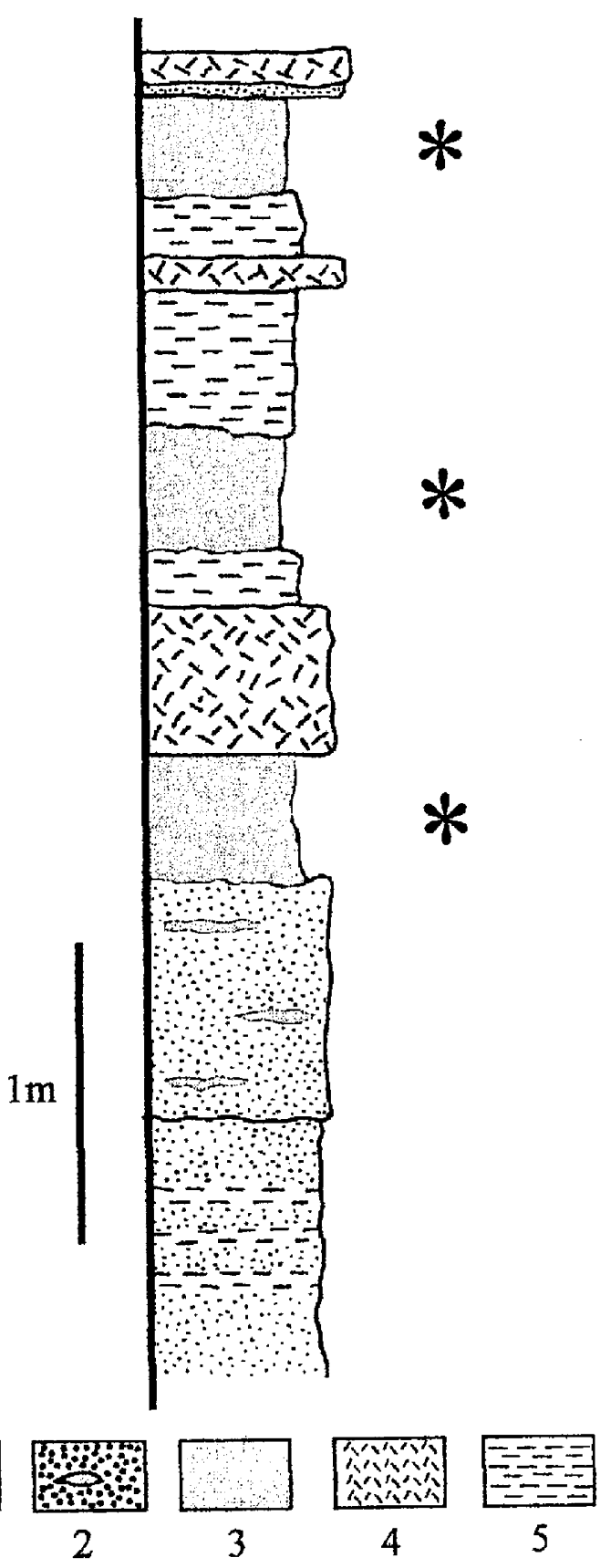

Fig. 2. Stratigraphic section at the upper part of the clayey lacustrine unit at the Rifreddo site. $1=$ sand with clayey intercalations; $2=$ sand with coal intercalations; 3 = peaty-clay; $4=$ tephra; $5=$ grey clay; $*$ The position of screen sieved samples.

molluscs, while fossil vertebrate are scarce. Above this level a thin $(0.02 \mathrm{~m})$ laminated sandy bed occurs, which is overlaid by a third tephra horizon $(0.1 \mathrm{~m})$.

To avoid misunderstandings in the use of chronostratigraphic terminology, in the present paper we use the definition of the Early/Middle Pleistocene transition proposed by Ruggieri et al. (1984) that places the boundary in correspondence to IOS22, the first pronounced 'glacial' peak that marks the beginning of the 
'full glacial' regime. Therefore, the boundary shortly post-dates the upper limit of Jaramillo Subchrone of the GPTS.

\section{Rifreddo fauna}

The following taxa have been identified in the Rifreddo sequence.

Pisces indet.

Amphibia

Triturus sp., Rana sp., Bufo cf. viridis.

Reptilia

Chelonii indet., Lacertidae indet., Colubrines indet., Serpentes indet.

Mammalia

Insectivora: Talpa cf. romana Crocidura kornfeldi, Sorex gr. runtonensis-subaraneus, Macroneomys cf. brachygnathus.

Lagomorpha: Leporidae indet.

Rodentia: Allocricetus cf. bursae, Apodemus gr. sylvaticus-flavicollis, Mimomys savini, Microtus (Terricola) arvalidens, Microtus (Iberomys) ex gr. huescarensisbrecciensis, Microtus sp.

\subsection{Description and remarks}

\subsubsection{Pisces}

Pisces indet Fig. 3(10, 11).

Material: 1 vertebrae.

One single tiny biconcave vertebra indicates the occurrence of a fish in the vertebrate assemblage of Rifreddo.

\subsubsection{Amphibia}

Triturus sp. Fig. 3(5, 6).

Material: 1 humerus; 1 dorsal vertebra.

The anterior portion of a small dorsal vertebra (fragment length: $1.3 \mathrm{~mm}$ ) belongs to a newt. The vertebral body is anteriorly convex (therefore the vertebra was probably opisthocoelous), the praezygapophyseal facets are narrow and long and the ventral foramina are relatively small. Besides the few features perceivable on the specimen, its allocation to the genus Triturus is also supported by the geographical and chronological position of the faunal assemblage. A small humerus is assigned to the same taxon.

Bufo cf. viridis Fig. 3(7).

Material: 2 ilia; 1 humerus.

The genus Bufo is represented by a humerus and two badly damaged ilia. The first element displays a laterally placed condyle and wide olecranon scar, while the second do not show ilial crests. Both are relatively robust. The occurrence of a small fossa preacetabularis in one of the ilia could suggest the presence of Bufo viridis.
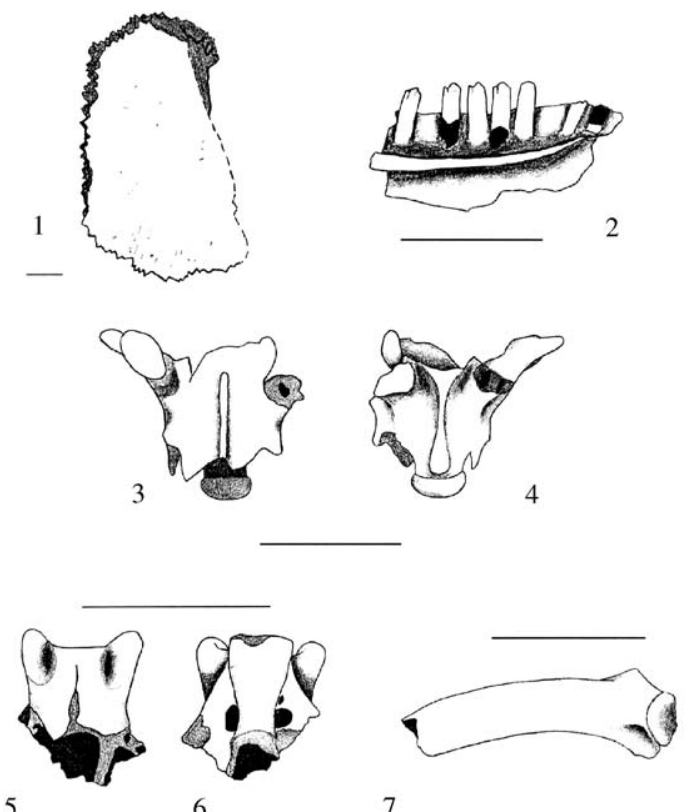

5

7

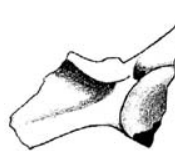

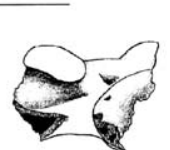

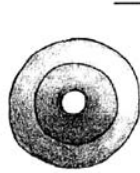

10

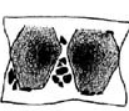

11
Fig. 3. Chelonii indet.: $1-$ neural plate, dorsal view; Lacertidae indet.: 2-dentary, medial view; Colubrines indet.: 3, 4 -trunk vertebra, dorsal and ventral view; Triturus sp.: 5, 6-trunk vertebra, dorsal and ventral view; Bufo cf. B. viridis: 7-ilium, lateral view; Rana sp.: 8, 9 ilia, lateral view; Pisces indet.: 10, 11-vertebra, medial and lateral view; scale $=2 \mathrm{~mm}$.

Rana sp. Fig. 3(8, 9).

Material: 2 ilia.

Two ilia, characterised by a prominent ilial crest, belong to frog genus Rana and possibly to the green frog group because of the tuber superior development.

Anura indet.

Material: 1 angulosplenial; 6 radio-ulnae; 2 humeri; 8 tibio-fibulae; 1 vertebra; 1 urostyle; 21 indet.

Several remains simply referred to the group Anura do not include any features that suggest the presence of taxa additional to those already identified.

\subsubsection{Reptilia}

Chelonii indet. Fig. 3(1).

Material: 1 neural plate; 1 plate fragment.

A few highly fragmented shell remains testify to the presence of chelonians. Their poor state of preservation makes it impossible to establish whether they belong to turtles or tortoises.

Lacertidae indet. Fig. 3(2).

Material: 2 premaxillae; 10 dentaries; 3 pterigoids; 123 teeth-bearing bones; 5 articulars; 11 coronids; 2 quadrati; 8 frontals; 9 jugals; 1 postfrontal + postorbital; 
1 prefrontal; 17 humeri; 2 scapulae; 2 tibiae; 16 femuri; 20 coxals; 29 dorsal vertebrae; 3 sacral vertebrae; 2 caudal vertebrae; 5 vertebrae indet.

Lizards are the most common elements among the whole herpetofauna.

Although highly fragmented, several remains coming from every anatomical district have been identified. The tooth-bearing bones show bicuspid pleurodont teeth, enabling the identification of the family Lacertidae. The size of the remains suggests the presence of small lacertids (smaller than the genus Podarcis on average).

A few elements display a greyish coloration suggesting that they have been burnt.

Colubrines indet Fig. 3(3, 4).

Material: 13 dorsal vertebrae.

Some dorsal snake vertebrae devoid of hypapophyses can be ascribed to the working taxon "Colubrines" (that is to say the non-Natricine Colubrids, Szyndlar, 1991). The vertebrae are relatively small and differ in terms of general morphology and haemal keel development. These differences could reflect the presence of mixed taxa.

Serpentes indet.

Material: 1 tooth; 3 teeth-bearing bones; 38 dorsal vertebrae; 9 caudal vertebrae; 14 vertebrae indet.; 5 ribs.

Several other fragmentary remains (or remains of no taxonomic value) have been referred to at order level and could well represent different taxa.

\subsubsection{Mammalia}

2.1.4.1. Insectivora. Talpa $\mathrm{cf}$ romana Fig. 4(1).

Material: 1 left $\mathrm{M}^{2}$.

The size (length $=2.27$, width $=3.09$ ) and the morphology of a single $\mathrm{M}^{2}$ from Rifreddo are characteristic of a large sized mole. The morphology of the tooth is similar to that of Talpa romana. In the Italian peninsula, this species is documented during the Middle and Late Pleistocene in the following localities: Visogliano, Cengelle, Viatelle and Castelcivita (Masini and Abbazzi, 1997; Fanfani, 1999; Abbazzi et al., 2000).

Crocidura kornfeldi Fig. 4(2-6), Table 1.

Material: (level I)-1 left I $\backslash 1 ; 1$ left $\mathrm{A} \backslash 1 ; 1$ left $\mathrm{A}^{2}$; 1 right $\mathrm{M}^{2} ; 1$ fragment of left $\mathrm{M}^{1} ; 1$ posterior fragment of right mandible; 1 posterior fragment of left mandible; 1 fragment of right mandible with $\mathrm{M}_{1}-\mathrm{M}_{2} ; 1$ fragment of right mandible with $\mathrm{M}_{2} ; 1$ fragment of left mandible with $\mathrm{P}_{4} ; 4$ fragments of right mandibles; 2 fragments of left mandibles and 1 right $\mathrm{P}_{4}$; (level III) - 1 left $\mathrm{M}_{2}$.

The upper incisor can be assigned to Crocidura by the absence of pigmentation in the main cusp, by the poorly developed rear cusp and by the absence of a lateral cusp (not fissident according to the terminology by Reumer, 1984). The colourless molars, the morphology of the condyle and the $\mathrm{P}_{4}$ are typical of the genus.

The size of the molars and of the mandibular ramus of the Rifreddo shrew is greater than that of $C$. suaveolens
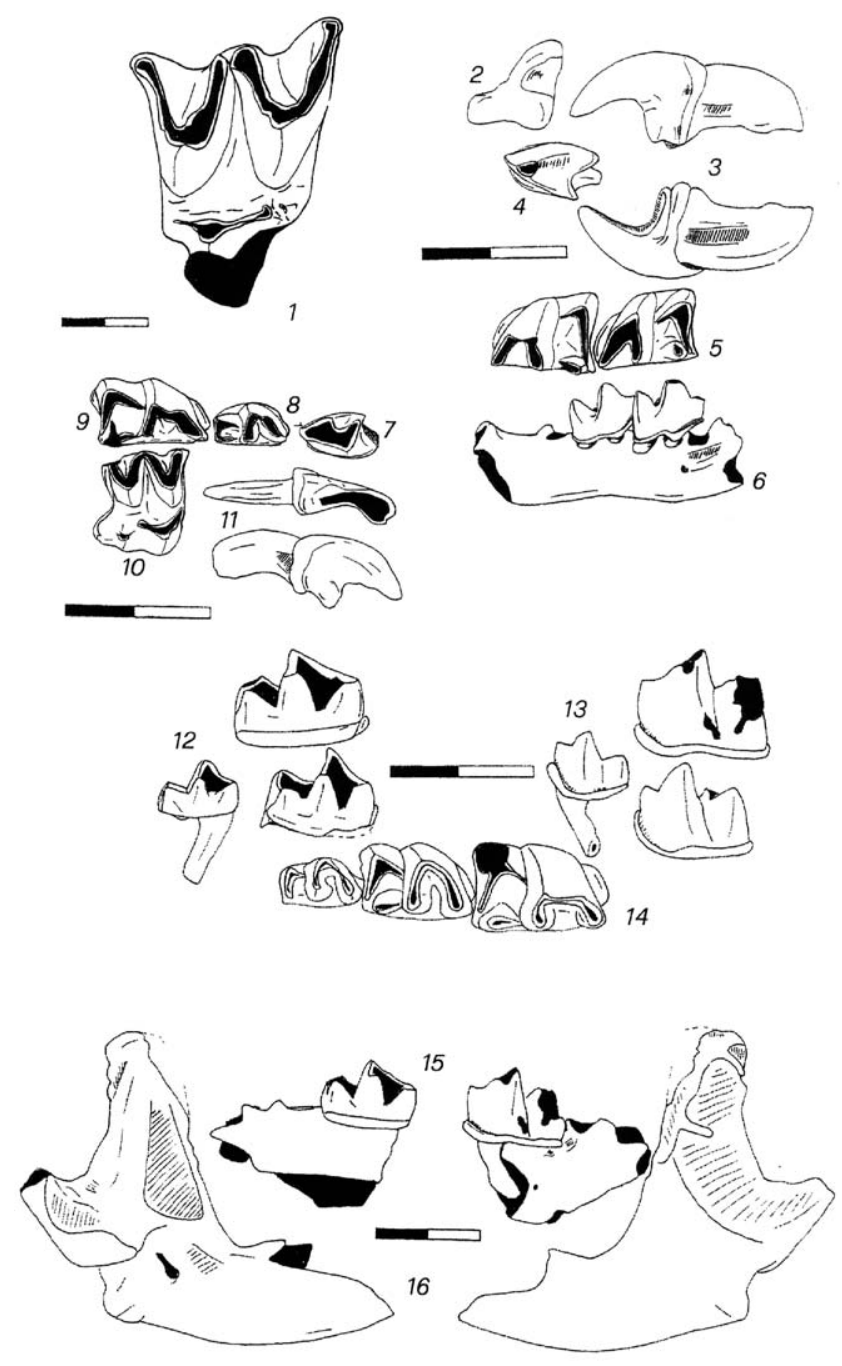

Fig. 4. Talpa cf. romana: 1 -left $\mathrm{M}^{2} ;$ C. kornfeldi: 2 -right mandibular condyle; 3-labial and lingual views of left $\mathrm{I}^{1} ; 4$-right $\mathrm{P}_{4} ; 5,6$ occlusal and labial views of right mandible with $\mathrm{M}_{1}-\mathrm{M}_{2}$; Sorex gr. subaraneus-runtonensis: 7-left $\mathrm{P}_{4} ; 8$-left $\mathrm{M}_{3} ; 9$-left $\mathrm{M}_{1} ; 10$-right $\mathrm{M}_{2} ; 11$-occlusal and labial views of right $\mathrm{I}^{1} ;$ Macroneomys $\mathrm{cf}$. brachygnathus: 12 -lingual view of $\mathrm{M}_{1}-\mathrm{M}_{3} ; 13$-labial view of $\mathrm{M}_{1}-\mathrm{M}_{3} ; 14-$ occlusal view of $\mathrm{M}_{1}-\mathrm{M}_{3} ; 15$-lingual and labial views of anterior fragment of right mandible with $\mathrm{M}_{1} ; 16$ - lingual and labial views of posterior fragment of right mandible.

Table 1

Measurements (mm) of Crocidura kornfeldi

\begin{tabular}{llll}
\hline & Length & Anterior width & Posterior width \\
\hline Left $\mathrm{M}^{2}$ & 1.31 & - & 1.74 \\
& Length & Trigonid width & Talonid width \\
\hline Right $\mathrm{P}_{4}$ & 1.00 & 0.79 & \\
Right $\mathrm{M}_{1}$ & 1.41 & 0.99 & 1.09 \\
Right $\mathrm{M}_{2}$ & 1.37 & 0.77 & 0.85 \\
Right $\mathrm{M}_{2}$ & 1.34 & 0.92 & 1.06 \\
Left $\mathrm{M}_{2}$ & 1.35 & 0.87 & 0.89 \\
\hline
\end{tabular}


and falls within the variation range of the species $C$. kornfeldi from several European localities. The first occurrence of this species is in the late Pliocene deposits of Central-Eastern Europe. At approximately the same time, this shrew is also recorded in Italy (locality Montagnola Senese, Fondi, 1972; Fanfani, 1999). In the Italian peninsula, even though not very commonly, C. kornfeldi occurs in the Early Pleistocene (Cava Pirro \& Dell'Erba) as well at Middle Pleistocene localities (lower levels of Visogliano Shelter, Abbazzi et al., 2000); the late Middle Pleistocene locality of Tre Fossi-F20 (Gargano promontory, unpublished) is probably its most recent occurrence.

Sorex gr. runtonensis-subaraneus Fig. 4(7-11), Table 2.

Material: 1 right $\mathrm{I}^{1} ; 1$ fragment of left maxilla with $\mathrm{P}^{4}-\mathrm{M}^{1} ; 1$ right $\mathrm{M}^{2} ; 1$ fragment of right $\mathrm{I}^{1} ; 1$ right $\mathrm{P}_{4} ; 1$ right $M_{1} ; 1$ right $M_{2} ; 1$ left $M_{3} ; 1$ fragment of left mandible with $\mathrm{M}_{1} ; 1$ fragment of right mandible; 1 fragment of left coronoid process.

These teeth are characterised by an evident variation in the intensity of pigmentation at the cusp tips. The actual colour of the teeth cannot be observed owing to the very dark, blackish staining caused by fossilisation. The pigmented teeth, the fissident incisor, the occurrence of a posterior basin in $\mathrm{P}_{4}$, an unreduced talonid basin in $\mathrm{M}_{3}$ and the upper molar morphology allow the assignation of all these specimens to the genus Sorex. The sizes of the Rifreddo remain are smaller than those of $S$. araneus but distinctly larger than those of $S$. minutus. The following morphological features enable these remains to be attributed to $S$. runtonensis or to $S$. subaraneus: the high

Table 2

Measurements (mm) of Sorex gr. runtonensis-subaraneus from Rifreddo

\begin{tabular}{llll}
\hline & Length & Anterior width & Posterior width \\
\hline Left $\mathrm{P}^{4}$ & 1.29 & 1.32 & \\
Left $\mathrm{M}^{1}$ & 1.24 & 1.30 & - \\
Right $\mathrm{M}^{2}$ & 1.18 & 1.32 & - \\
& Length & Trigonid width & Talonid width \\
\hline Right $\mathrm{P}_{4}$ & 0.69 & 0.60 & \\
Left $\mathrm{M}_{1}$ & 1.39 & 0.81 & 0.82 \\
Right $\mathrm{M}_{2}$ & 1.20 & 0.64 & 0.73 \\
Left $\mathrm{M}_{3}$ & 0.94 & 0.45 & 0.30 \\
\hline
\end{tabular}

cusped $\mathrm{P}_{4}$ with a strong labial cingulum, the lower molars with a mesially stretched paraconid and high rear cusp curved distally, the thick labial cingulum and the welldeveloped talon of the upper incisor, the squarish shape of the upper molar and its poorly expanded hypoconal flange. The distinction between these two closely related species is very subtle and, in many cases not absolutely reliable (see Rzebik-Kowalska, 1991; Fanfani, 1999, for a more exhaustive discussion) despite the fact that the mandibles from both type localities differ in size from each other (Table 3). When populations from localities of different geographic location and age are considered (Maul, 1990b; Rzebik-Kowalska, 1991, 2000; Fanfani, 1999), one can observe that the size ranges of the two species is somewhat overlapping. The size of the isolated teeth from Rifreddo falls within the superposition zone. Therefore, since we are dealing with not abundant, fragmentary, material we prefer to use the terminology $S$. gr. runtonenis-subaraneus for the Rifreddo specimens.

Shrews of the S. runtonensis-subaraneus group were widespread in the Pleistocene of the European regions (Rzebik-Kowalska, 1998, 2000). Their first occurrence is in Deutsch Altenburg 30A, an Early Pleistocene locality in Austria (S. runtonensis, Mais and Rabeder, 1984) and Montoussé 5 (S. subaraneus, Late Pliocene, MN17, Clot et al., 1976). The last occurrence of these species is in the Late Pleistocene (Rzebik-Kowalska, 1998). Fully comparable remains to those of Rifreddo occur in the Italian Regions in the Middle Pleistocene localities of Cengelle, Viatelle, Visogliano, Valdemino and Bosco Chiesanova. The most recent finds of $S$. gr. runtonensis-subaraneus are those of Scario SG (Fanfani, 1999) attributed to IOS6 by Maul et al. (1998).

Macroneomys cf. brachygnathus Fig. 4(12-16), Table 4.

Material: (level I)-1 fragment of $\mathrm{M}^{3} ; 1$ left $\mathrm{M}^{2} ; 1$ fragmented left mandible with $\mathrm{M}_{1}-\mathrm{M}_{3} ; 1$ left $\mathrm{M}_{2}$; (level III)-1 right $\mathrm{M}_{2}$.

The occurrence of a very large sized Neomyini shrew in the Rifreddo assemblage is documented by a fragmented left mandible with $\mathrm{M}_{1}-\mathrm{M}_{3}$ and a single left $\mathrm{M}_{2}$ (Fig. 4; Table 4). These remains can be positively assigned to the genus Macroneomys by their size, the short and massive aspect of the mandible, the stout and large condyle, the strong development of the coronoid process, the raised and thin coronoid spicula, the bulbous and short ("exoedaenodont") aspect of molars and the large size

\begin{tabular}{|c|c|c|c|c|c|c|c|c|}
\hline & \multicolumn{4}{|c|}{ Height of the coronoid process } & \multicolumn{4}{|c|}{ Length M1-M3 } \\
\hline & $n$ & Min & $x$ & Max & $n$ & Min & $x$ & Max \\
\hline Erpfingen (1) & 22 & 4.1 & 4.26 & 4.4 & 5 & 3.8 & 3.84 & 3.9 \\
\hline West Runton (2) & 21 & 3.4 & 3.96 & 4.2 & 22 & 3.3 & 3.55 & 3.8 \\
\hline
\end{tabular}


of $M_{1}$ relatively to $M_{2}$.

The Rifreddo remains are morphologically and dimensionally similar to the species Macroneomys brachygnathus (Fejfar, 1966). The mandible has a high and wide ascending branch that is, however, somewhat lower than that of the holotype of $M$. brachygnathus from Konĕprusy C718 (Late Biharian, Czech Republic; Fejfar, 1966) and from other specimens attributed to this genus (Table 5). The coronoid process is straight in the Rifreddo specimen and slightly bending mesialwards in the specimens from Koněprusy and Voigtstedt (Late Biharian, Maul and Rzebik-Kowalska, 1998). The characteristic of the Rifreddo mandible can also be observed in the specimens from la Fage, referred to as Macroneomys cf. brachygnathus by Jammot (1973). The morphological variation of the inclination of the coronoid process has, however, been considered as not particularly significant by Maul and Rzebik-Kowalska (1998). Taking into account that we are dealing with a single specimen, and also that the material for comparison is rather poor (five specimens, see Table 5), we have assigned the Rifreddo remains to $M$. cf. brachygnathus.

Macroneomys brachygnathus is rare but geographically widespread in the middle and the late part of the Middle Pleistocene in Eastern and Central Europe. In northeastern Italy (lower levels of Visogliano Shelter) a different species has been recognised and tentatively referred to as Macroneomys sp. by Fanfani (1998).

Table 4

Measurements (mm) of Macroneomys cf. brachygnathus from Rifreddo

\begin{tabular}{llll}
\hline & Length & Anterior width & Posterior width \\
\hline Left M & & & \\
& 1.56 & 2.03 & 1.65 \\
& Length & Trigonid width & Talonid width \\
\hline Left $\mathrm{M}_{1}$ & 1.92 & 1.22 & 1.29 \\
Left $\mathrm{M}_{2}$ & 1.65 & 0.99 & 1.01 \\
Left $\mathrm{M}_{2}$ & 1.76 & 0.96 & 1.05 \\
Right $_{2}$ & 1.82 & 1.01 & - \\
Left $\mathrm{M}_{3}$ & 1.12 & 0.63 & 0.56 \\
Height of coronoid process & & \\
Left mandible & 5.94 & & \\
\hline
\end{tabular}

According to the last author, other large sized Neomyini from north-eastern Italy (Pasa collections: San Vito di Leguzzano, Bosco Chiesanuova, San Giovanni di Duino) referred to as "Nesiotites" sp. by Bartolomei (1966, 1969, 1976), belong to the same genus. It is apparent that the first appearance of Macroneomys did not occur before the Brunhes/Matuyama boundary, as can also be inferred by the positive magnetisation of the site of Voigtstedt and Kozi Grzbiet: its last occurrence is recorded at La Fage, a late Middle Pleistocene (early Toringian) site in France. For an exhaustive discussion on the chronological significance of this shrew see Maul and Rzebik-Kowalska (1998). Macroneomys cf. brachygnathus from Rifreddo is the southernmost occurrence of the genus in the Italian Peninsula.

\subsubsection{Lagomorpha. Leporidae indet Fig. 5(1, 2).}

Material: 1 right $\mathrm{P}^{3} ; 1$ left $\mathrm{M}^{1}$ or $\mathrm{P}^{4} ; 1$ undeterminable fragment of an upper jugal tooth.

The material is too scarce for a more precise identification, although the large size of the remains allows members of the family Ochotonidae to be excluded.

2.1.4.3. Rodentia. Allocricetus cf. bursae Fig. 5(3-5), Table 6.

Material: 2 left $\mathrm{M}_{1} ; 2$ right $\mathrm{M}_{1} ; 2$ right $\mathrm{M}_{2} ; 1$ left $\mathrm{M}_{2} ; 1$ right $\mathrm{M}_{3} ; 1$ right $\mathrm{M}^{1} ; 1$ right $\mathrm{M}^{2}$; left $\mathrm{M}^{2}$.

A small sized hamster referred to as Allocricetus cf. bursae is represented at Rifreddo by some teeth (Table 6, Fig. 5). Their measurements agree with those reported for some Italian Early and Middle Pleistocene populations of $A$. bursae (e.g. Visogliano, Abbazzi et al., 2000; Monte La Mesa, Marchetti et al., 1999, respectively) as well as with those of $A$. bursae duraciensis from some French Middle Pleistocene sites (e.g. Saint-EstèveJanson, Chaline, 1972).

In Italy, the oldest record of this genus is from the early Biharian locality of Monte La Mesa (Marchetti et al., 1999), where A. bursae and $A$. ehiki are documented. Allocricetus also occurs in faunal assemblages of the Middle and early Late Pleistocene, and therefore it has no a particular biochronological significance.

Table 5

Measurements (mm) of Macroneomys from European localities

\begin{tabular}{|c|c|c|c|c|c|}
\hline \multirow[t]{2}{*}{ Species } & \multirow[t]{2}{*}{ Age } & \multirow[t]{2}{*}{ Localities } & \multicolumn{3}{|c|}{ Height of the coronoid process } \\
\hline & & & Mean & $N$ & Min-max \\
\hline M. cf. brachygnathus & Early Toringian & La Fage & 6.78 & 1 & \\
\hline M. brachygnathus & Late Biharian & Koněprusy & 6.65 & 3 & $6.50-6.83$ \\
\hline M. brachygnathus & Late Biharian & Koněprusy & 6.50 & Holotype & \\
\hline M. brachygnathus & Late Biharian & Voigtstedt & 6.32 & 1 & \\
\hline Macroneomys sp. & Early Toringian & Visogliano & 5.30 & 2 & $5.29-5.31$ \\
\hline
\end{tabular}




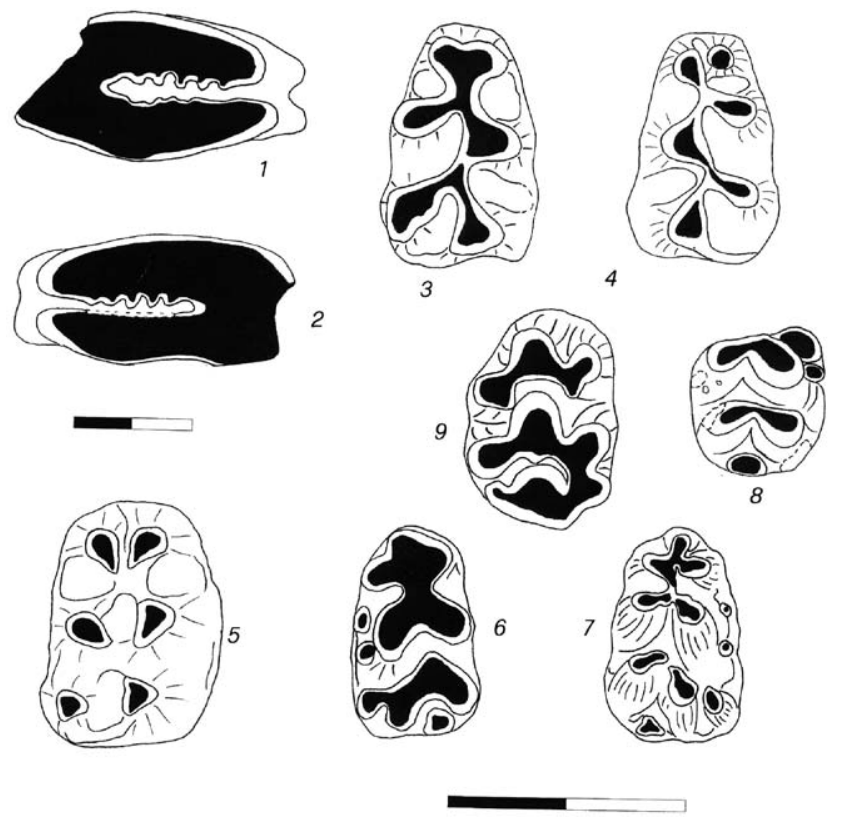

Fig. 5. Leporidae indet.: 1 -right $\mathrm{P}^{3}, 2$ - left $\mathrm{M}^{1}$ or $\mathrm{P}^{4}$; Allocricetus $\mathrm{cf}$. bursae: 3-right $\mathrm{M}_{1}, 4$ - left $\mathrm{M}_{1}, 5$-right $\mathrm{M}^{1}$; Apodemus gr. sylvaticusflavicollis: 6-left $\mathrm{M}_{1}, 7$-right $\mathrm{M}_{1}, 8$-right $\mathrm{M}_{2}, 9$-right $\mathrm{M}^{1}$.

Table 6

Measurements (mm) of $\mathrm{M}_{1}$ and $\mathrm{M}^{1}$ of Allocricetus cf. bursae from Rifreddo

\begin{tabular}{lll}
\hline & Length & Width \\
\hline Left $\mathrm{M}_{1}$ & 1.81 & 1.14 \\
Left $\mathrm{M}_{1}$ & 1.69 & $0.98^{\mathrm{a}}$ \\
Right $^{1}$ & $1.92^{\mathrm{a}}$ & 1.21 \\
Right $\mathrm{M}_{1}$ & 1.88 & 1.18 \\
Right $\mathrm{M}^{1}$ & 2.00 & 1.40 \\
\hline
\end{tabular}

${ }^{\mathrm{a}}$ Inferred value.

Apodemus gr. sylvaticus-flavicollis Fig. 5(6-9), Table 7.

Material: 1 left $\mathrm{M}^{1} ; 2$ left $\mathrm{M}_{1} ; 1$ right $\mathrm{M}_{1} ; 1$ right $\mathrm{M}_{2} ; 1$ left $\mathrm{M}_{2} ; 1$ left $\mathrm{M}_{3}$.

This murid can be easily ascribed to the A. sylvaticusflavicollis group. Its size, slightly smaller than that of $A$. flavicollis (data according to Pasquier, 1974) and $\mathrm{M} / 2$ with two accessory cusps on a well developed labial cingulum, suggest that at least some teeth could belong to $A$. sylvaticus. These two species appear in the Italian Peninsula in the late part of the Early Pleistocene (Argenti, 1998) and are continuously present in the Quaternary rodent assemblages. Their use for chronological purposes requires very large samples that allow a rather subtle morphological analysis (Argenti, 1998).

Mimomys savini.

Material: 1 fragment of upper molar, fragments of large rooted molars.

Some fragments of large rooted molars testify to the occurrence of a large vole, here referred to as Mimomys
Table 7

Measurements (mm) of $\mathrm{M}_{1}$ and $\mathrm{M}^{1}$ of Apodemus gr. sylvaticusflavicollis

\begin{tabular}{llc}
\hline & Length & Width \\
\hline Left $\mathrm{M}_{1}$ & 1.70 & 1.05 \\
Left $\mathrm{M}_{1}$ & 1.45 & 0.84 \\
Right $\mathrm{M}_{1}$ & 1.65 & 1.05 \\
Left $\mathrm{M}^{1}$ & 1.76 & 1.20 \\
\hline
\end{tabular}

savini, because of its size, the occurrence of crown cement and mimomyan-like differentiated enamel walls. This species is a typical member of the Biharian small mammal faunas and its more recent representatives are commonly found in positively magnetised sediments correlated with the early part of Brunhes (e.g. Voigtstedt, West Runton, Přezletice). It is gradually replaced by its unrooted descendant Arvicola, in a time interval roughly estimated as 0.6-0.5 Ma (e.g. von Koenigswald and van Kolfschoten, 1996).

Microtus (Terricola) arvalidens Fig. 6(1-12), Fig. 7, Tables 8 and 9.

Material: 6 left $\mathrm{M}_{1} ; 6$ right $\mathrm{M}_{1} ; 10$ anterior fragments of left $\mathrm{M}_{1} ; 10$ anterior fragments of right $\mathrm{M}_{1} ; 1$ posterior fragments of left $\mathrm{M}_{1} ; 3$ posterior fragments of right $\mathrm{M}_{1} ; 3$ left $\mathrm{M}^{3}, 2$ right $\mathrm{M}^{3}$.

This vole is the most common small mammal in the Rifreddo section. $\mathrm{M}_{1}$ is slender with unmarked buccolingual asymmetry. Triangles are characterised by microtine differentiated enamel walls. ACC is elongated, T4-T5 form a pitymyoid rhomb with a various degree of constriction $(\mathrm{C} / \mathrm{W}$ index ranging from 12.50 to 31.43 , see Table 9); T6-T7 are usually well developed and confluent to form a 'rhomb' complex. LR4A, and sometimes LR3A, tend to be $U$-shaped and not mesially directed (not provergent according to terminology of Rabeder, 1981) as in several subgenera of Microtus. This feature is also observed, though rarely, in primitive 'true' Microtus, and apparently becomes very common in evolved $M$. (Terricola) species, possibly partly related to the occurrence of confluent, opposed T4-T5 and T6-T7. Posterior enamel wall in some specimens has a sinuous profile; the hint of a small triangle (T8 ?) is visible on the labial side of $\mathrm{AC}$ of two specimens (Fig. 6.2). A slight confluence between T1 and T2 can be observed in several specimens (Fig. 6). $\mathrm{M}^{3}$ is simple, triangles are closed. The slender and small sized $M$. (Terricola) $\mathrm{M}_{1}$ 's from Rifreddo might recall some morphotypes of the modern $M$. (T.) subterraneus, as already observed by Brunet-Lecomte and Chaline (1990) for other populations of $M$. (T.) arvalidens.

The sample from Rifreddo has been compared with other Microtus (Terricola) species from Middle-Late Pleistocene and Recent Italian localities and with extant samples of $M$. (T.) lusitanicus and of $M$. (T.) subterraneus from Spain and France, respectively. In Fig. 8 the 


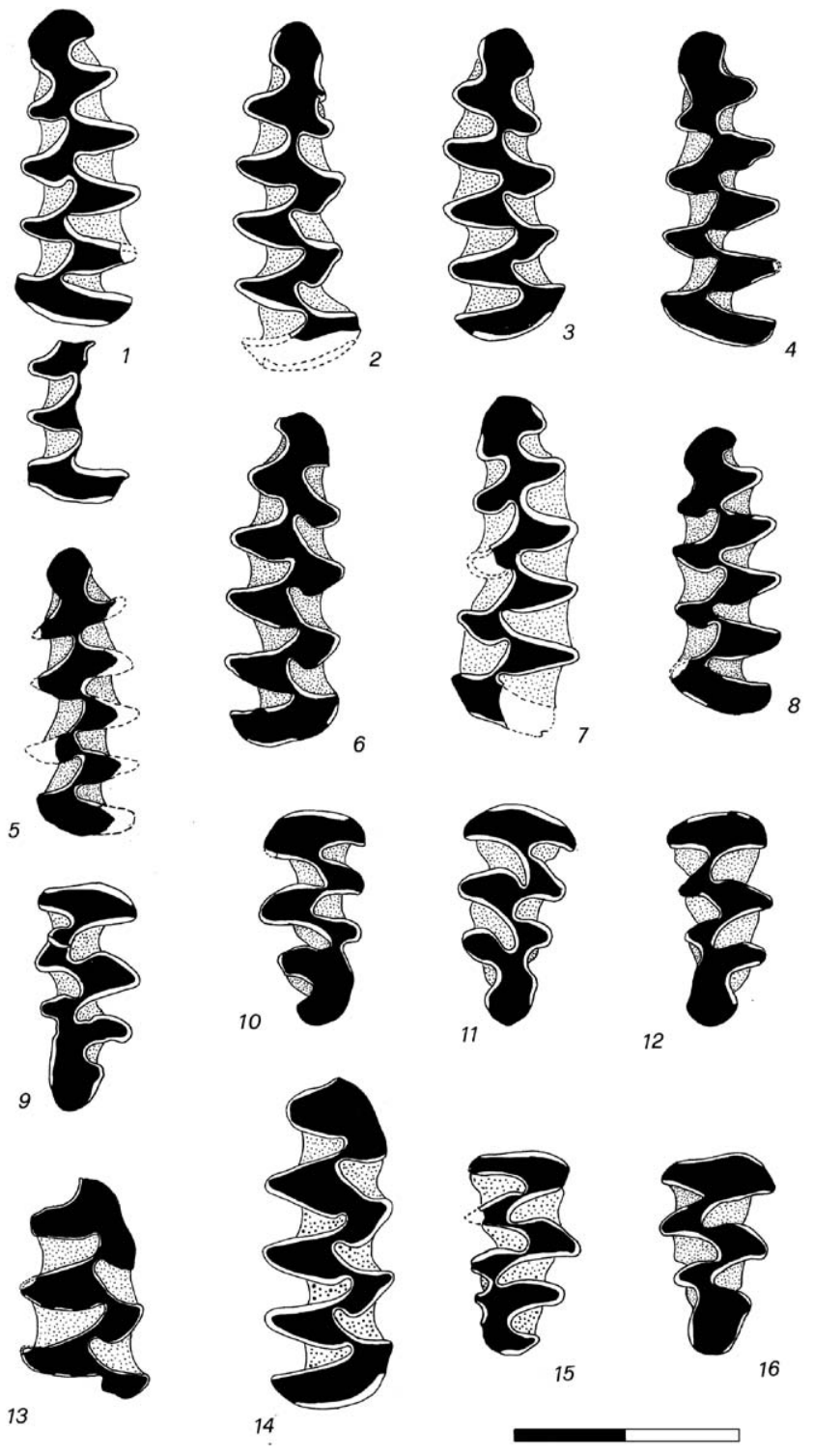

Fig. 6. Microtus (Terricola) arvalidens: 1 - left $\mathbf{M}_{1}-\mathrm{M}_{2} ; 2$-right $\mathrm{M}_{1}$; 3-right $\mathrm{M}_{1} ; 4$-left $\mathrm{M}_{1} ; 5$-left $\mathrm{M}_{1} ; 6$-right $\mathrm{M}_{1} ; 7$-left $\mathrm{M}_{1} ; 8$-left $\mathrm{M}_{1} ; 9$-right $\mathrm{M}^{3} ; 10$-left $\mathrm{M}^{3} ; 11$-left $\mathrm{M}^{3} ; 12$-right $\mathrm{M}^{3}$; Microtus (Iberomis) ex gr. huescarensis-brecciensis: 13-fragment of right $\mathrm{M}_{1}$; 14 -right $\mathrm{M}_{1} ; 15$-right $\mathrm{M}^{3}$; Microtus sp.: 16-right $\mathrm{M}^{3}$.

comparison between $\mathrm{A} / \mathrm{L}$ and $\mathrm{C} / \mathrm{W}$ ratios is reported. The $\mathrm{M}_{1}$ 's from Rifreddo are close to Isernia and Visogliano samples, and to $M$. (T.) subterraneus as well; they are particularly distinct from fossil and recent $M$. (T.) savii because of the significant lower degree of T4-T5 confluence. In terms of ACC development (Fig. 9, in which indices $\mathrm{A} / \mathrm{L}$ and $\mathrm{A} 2 / \mathrm{A}$ are compared), the Rifreddo sample occupies an intermediate position between the $M$. (T.) savii group and $M$. (T.) subterraneus and lusitanicus, clustering very close to the sample of Isernia, Visogliano, and also SS3, an Eemian savii population form Apulia (Southern Italy). Finally, in Fig. 10 one can observe again the clear separation of the savii group, which has a rather wide confluence between T6-T7 and the anterior loop. One can also observe that the Isernia sample is distinguishable from the arvalidens populations from Visogliano and Rifreddo in having high $\mathrm{D} / \mathrm{E}$ index values, comparable to those of the savii group.

M. (T.) arvalidens is documented in late Early Pleistocene-Middle Pleistocene European localities: it is most widespread in eastern region such as Hungary, Poland and Ukraine, but it is also common in all other areas of Europe, including Germany and France (for compilations see Maul, 1990a; Rekovets and Nadachowski, 1995; Cuenca-Bescos et al., 1999).

In the case of the Italian Peninsula, a single $\mathrm{M}_{1}$ of $M$. (T.) arvalidens has been reported by De Giuli and Torre (1984) from the fissure filling Pirro Nord 1 (Gargano, Italy) associated to an early Biharian fauna including $M$. (Allophaiomys) cf. ruffoi. However, the presence of $M$. (T.) arvalidens has not been substantiated by the huge amount of small vertebrate remains collected in the subsequent years from many fissure fillings in the same area (cf. De Giuli et al. 1987; Masini and Santini 1991; Abbazzi et al., 1996; Lippi, 1997; Masini et al., 1998). Therefore, the occurrence of this vole in the early Biharian of southern Italy must be considered unreliable. Apparently, the youngest record of Microtus (Terricola) arvalidens is represented by the finds from the lower levels of the Visogliano Shelter (this paper), previously referred to as M. (Terricola) sp. by Maul et al. (1998) and Abbazzi et al. (2000) in association with a Toringian small mammal assemblage. The finds from Rifreddo are the oldest record of this species in Italy. Microtus (Terricola) gr. multiplexsubterraneus from Isernia (Sala, 1996) could also be closely related to this species. There is a general agreement in the literature (cf. Cuenca-Bescos et al., 1999) that the first occurrence of this vole predates the Brunhes/Matuyama boundary and post-dates the Jaramillo Subchrone. Its last occurrence is usually documented within the early Toringian, but this date is perhaps biased by the close morphological affinity of the arvalidens vole to $M$. (Terricola) subterraneus.

Microtus (Iberomys) ex gr. huescarensis-brecciensis Fig. 6(13-15), Tables 8 and 9.

Material: 1 right $\mathrm{M}_{1} ; 1$ fragment of right $\mathrm{M}_{1} ; 1$ right $\mathrm{M}^{3}$, 1 left $\mathrm{M}^{3}$.

The $\mathrm{M}_{1}$ 's referred to as Microtus (Iberomys) ex gr. huescarensis-brecciensis are characterised by a fairly large size (Table 8) and have strongly alternated triangles and well-developed lingual triangles, typical of this subgenus. The complete $\mathrm{M} / 1$ is characterised by confluent T4-T5, while the fragmented $\mathrm{M}_{1}$ shows alternating T4-T5 (see index $\mathrm{C} / \mathrm{W}$ in Tables 8 and 9). The $\mathrm{AC}$ is short with a triangular shape; T7 is well developed with a blunted lingual end, while the labial corner that always occurs in the more derived Middle Pleistocene and Late Pleistocene forms (e.g. modern M. brecciensis) is lacking from both specimens. The Rifreddo sample shows Iberomys traits 
Table 8

Measurements of $\mathrm{M}_{1}$ of Microtus (Terricola) arvalidens and Microtus (I.) ex gr. huescarensis-brecciensis from Rifreddo. Explanation of measurement labels in Fig. 7

\begin{tabular}{|c|c|c|c|c|c|c|c|c|c|c|c|}
\hline $\mathrm{L}$ & A & $\mathrm{A} 2$ & W & $\mathrm{C}$ & B & $\mathrm{E}$ & $\mathrm{D}$ & L5 & L4 & Wla & Wli \\
\hline \multicolumn{12}{|c|}{ M. (T.) arvalidens } \\
\hline 2.73 & 1.38 & 0.86 & 0.83 & 0.15 & 0.03 & 0.67 & 0.29 & 1.73 & 1.43 & - & - \\
\hline 2.49 & 1.27 & 0.74 & 0.83 & 0.14 & 0.02 & 0.69 & 0.25 & 1.62 & 1.37 & - & - \\
\hline 2.73 & 1.41 & 0.88 & 0.93 & 0.13 & 0.02 & 0.75 & 0.13 & 1.66 & 1.35 & - & - \\
\hline 2.44 & 1.27 & 0.72 & 0.70 & 0.22 & 0.03 & 0.69 & 0.17 & 1.49 & 1.38 & - & - \\
\hline 2.36 & 1.18 & 0.67 & 0.85 & 0.13 & 0.03 & 0.66 & 0.21 & 1.21 & 0.97 & - & - \\
\hline 2.75 & 1.46 & 0.89 & 0.76 & 0.16 & 0.02 & 0.68 & 0.24 & 1.74 & 1.54 & - & - \\
\hline 2.65 & 1.41 & 0.77 & 0.87 & 0.15 & 0.03 & 0.74 & 0.28 & 1.66 & 1.38 & - & - \\
\hline 2.75 & 1.38 & 0.85 & 0.91 & 0.12 & 0.02 & 0.74 & 0.12 & 1.72 & 1.39 & - & - \\
\hline 2.53 & 1.38 & 0.83 & 0.85 & 0.15 & 0.03 & 0.68 & 0.19 & 1.58 & 1.36 & - & - \\
\hline 2.74 & 1.37 & 0.70 & 0.76 & 0.18 & 0.02 & 0.61 & 0.24 & 1.89 & 1.63 & - & - \\
\hline 2.31 & 1.22 & 0.81 & 0.84 & 0.12 & 0.02 & 0.71 & 0.22 & 1.48 & 1.16 & - & - \\
\hline 2.49 & 1.29 & 0.82 & 0.88 & 0.11 & 0.02 & 0.71 & 0.14 & 1.50 & 1.32 & - & - \\
\hline \multicolumn{12}{|c|}{ M. (I.) gr. huesc.-brecc. } \\
\hline 2.73 & 1.4 & 0.68 & 0.98 & 0.14 & 0.02 & 0.85 & - & 1.85 & 1.62 & 0.32 & 0.66 \\
\hline - & 1.36 & 0.67 & 0.97 & 0.05 & 0.02 & - & - & - & - & 0.27 & 0.70 \\
\hline
\end{tabular}

Table 9

Morphological indices of Microtus (I.) ex gr. huescarensis-brecciensis $(1,2)$ and $M .(T$.$) arvalidens (3-14)$

\begin{tabular}{|c|c|c|c|c|c|c|c|}
\hline $\mathrm{A} / \mathrm{L}$ & $\mathrm{B} / \mathrm{W}$ & $\mathrm{C} / \mathrm{W}$ & $\mathrm{A} 2 / \mathrm{A}$ & $\mathrm{D} / \mathrm{E}$ & $\mathrm{E} / \mathrm{W}$ & L4/L5 & $\mathrm{D} / \mathrm{W}$ \\
\hline \multicolumn{8}{|c|}{ M. (T.) arvalidens } \\
\hline 50.55 & 3.61 & 18.07 & 62.32 & 43.28 & 80.72 & 82.66 & 34.94 \\
\hline 51.00 & 2.41 & 16.87 & 58.27 & 36.23 & 83.13 & 84.57 & 30.12 \\
\hline 51.65 & 2.15 & 13.98 & 62.41 & 17.33 & 80.65 & 81.33 & 13.98 \\
\hline 52.05 & 4.29 & 31.43 & 56.69 & 24.64 & 98.57 & 92.62 & 24.29 \\
\hline 50.00 & 3.53 & 15.29 & 56.78 & 31.82 & 77.65 & 80.17 & 24.71 \\
\hline 53.09 & 2.63 & 21.05 & 60.96 & 35.29 & 89.47 & 88.51 & 31.58 \\
\hline 53.21 & 3.45 & 17.24 & 54.61 & 37.84 & 85.06 & 83.13 & 32.18 \\
\hline 50.18 & 2.20 & 13.19 & 61.59 & 16.22 & 81.32 & 80.81 & 13.19 \\
\hline 54.55 & 3.53 & 17.65 & 60.14 & 27.94 & 80.00 & 86.08 & 22.35 \\
\hline 50.00 & 2.63 & 23.68 & 51.0938 & 39.34 & 80.26 & 86.24 & 31.58 \\
\hline 52.81 & 2.38 & 14.29 & 66.39 & 30.99 & 84.52 & 78.38 & 26.19 \\
\hline 51.81 & 2.27 & 12.50 & 63.57 & 19.72 & 80.68 & 88.00 & 15.91 \\
\hline \multicolumn{8}{|c|}{ M. (I.) gr. huesc.-brecc. } \\
\hline 51.28 & 2.04 & 14.28 & 48.57 & - & 86.73 & 87.56 & - \\
\hline- & 2.06 & 5.15 & 49.26 & - & - & - & - \\
\hline
\end{tabular}

Indices A/L, B/W, C/W were introduced by Van der Meulen (1973); D/ $\mathrm{W}\left(=\mathrm{W}^{\prime} / \mathrm{W}\right.$ in Martin, 1995), E/W by Cuenca-Bescos et al. (1995); A2/ A has been introduced by Bonfiglio et al. (1997), L4/L5 is here introduced based on the measurements of Brunet-Lecomte (1988).

(e.g. evident buccal-lingual asymmetry and the triangular shape of AC). The teeth from Rifreddo differ from $M$. (I.) huescarensis from Atapuerca (Cuenca-Bescos et al., 1999) in several derived traits, such as the less confluent T4-T5, the more provergent LRA4 and the absence of hintonilike AC morphotypes. Their morphology is closer to $M$. (I.) brecciensis mediterraneus (Chaline, 1972) from which it differs, however, in a number of primitive features such as the slightly shorter and simpler AC, the occurrence of slightly confluent $\mathrm{T} 4-\mathrm{T} 5$ in one specimen, the less

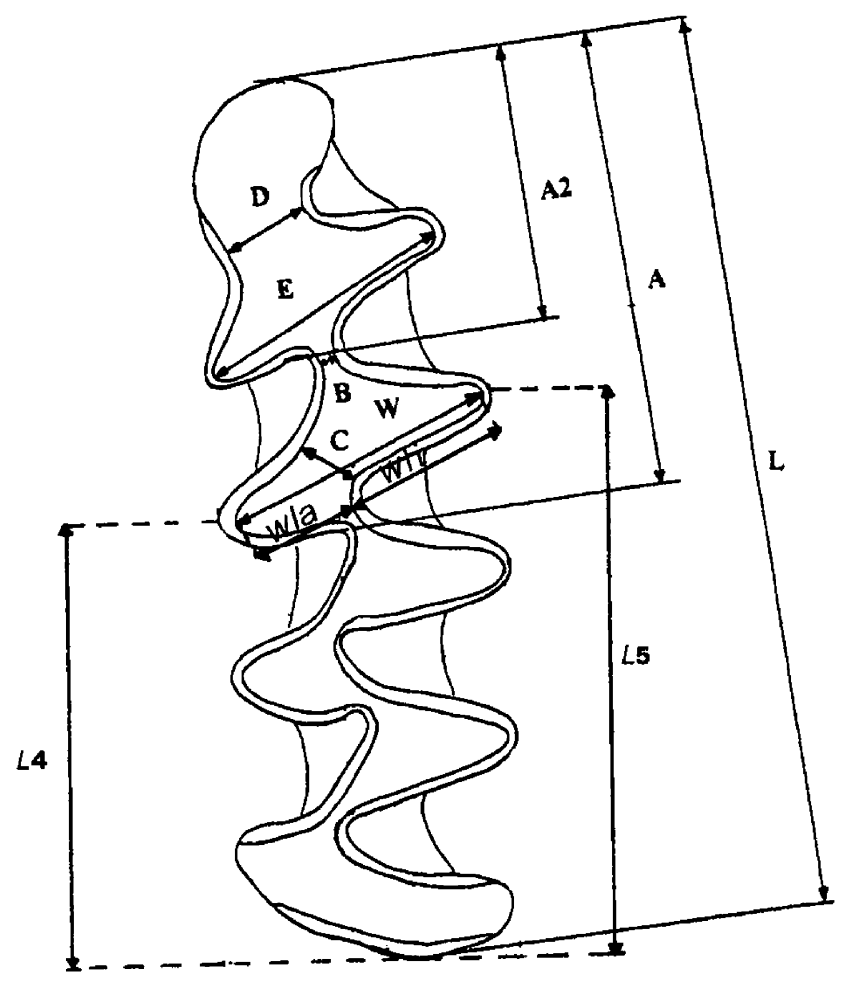

Fig. 7. Measurements for Microtus (Terricola) arvalidens and Microtus (Iberomys) ex gr. huescarensis-brecciensis. $\mathrm{L}=$ total length; $\mathrm{A}=$ length of the ACC complex; A2=length of the T6-T7/AC3 complex; $\mathrm{W}=$ width of pitymyoid rhombus; $\mathrm{D}=$ minimum width of $\mathrm{ACC}$ complex between LRA4 and BRA5; $\mathrm{E}=$ width of rhombus T6-T7. Measurements L, A, B, C, D, E, W in accordance to Van der Meulen (1973); A2 has been introduced by Bonfiglio et al. (1997); L4, L5, by Brunet-Lecomte (1988); Wla, Wli, by Cuenca-Bescos, et al. (1995).

developed T7, the complete absence of T9, and the less provergent LRA4 (see also Cuenca-Bescos et al., 1999 for the distinction between the two species). 


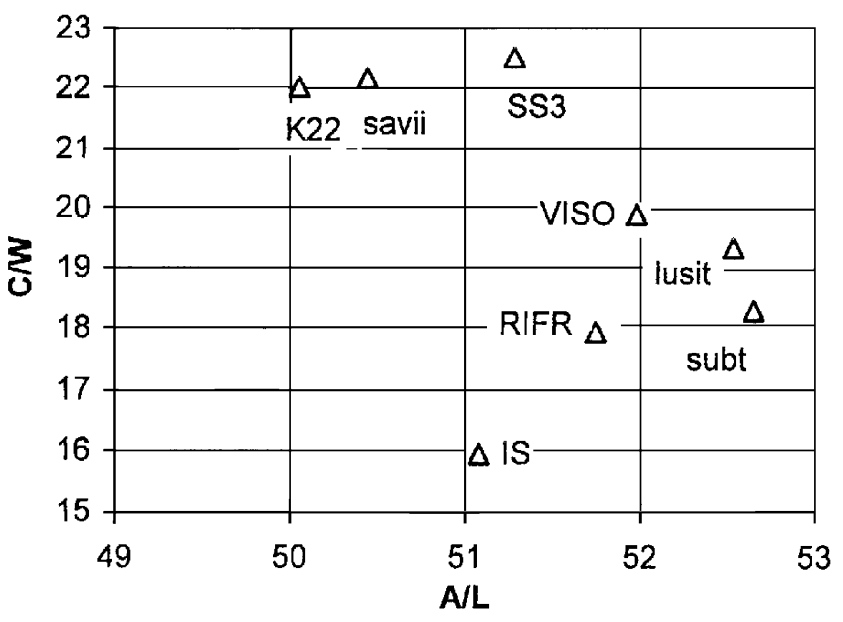

Fig. 8. Scatter diagram displaying mean values of $\mathrm{A} / \mathrm{L}$ vs. $\mathrm{C} / \mathrm{W}$ ratios of $\mathrm{M}_{1}$ 's of several M. (Terricola) samples. M. (T.) arvalidens from Rifreddo (RIFR), and Toringian lower levels of Visogliano Shelter (VISO), early Toringian $M$. (T.) multiplex-subterraneus from Isernia (IS), extant $M$. (T.) lusitanicus from Spain (lusit), extant $M$. (T.) subterraneus from France (subt), Eemian $M$. (T.) savii from San Sidero 3 (SS3), Late Glacial from Sicily (K22) and extant $M$. (T.) savii from Apulia (savii). Data from Bonfiglio et al. (1997) except Visogliano and Isernia (this paper).

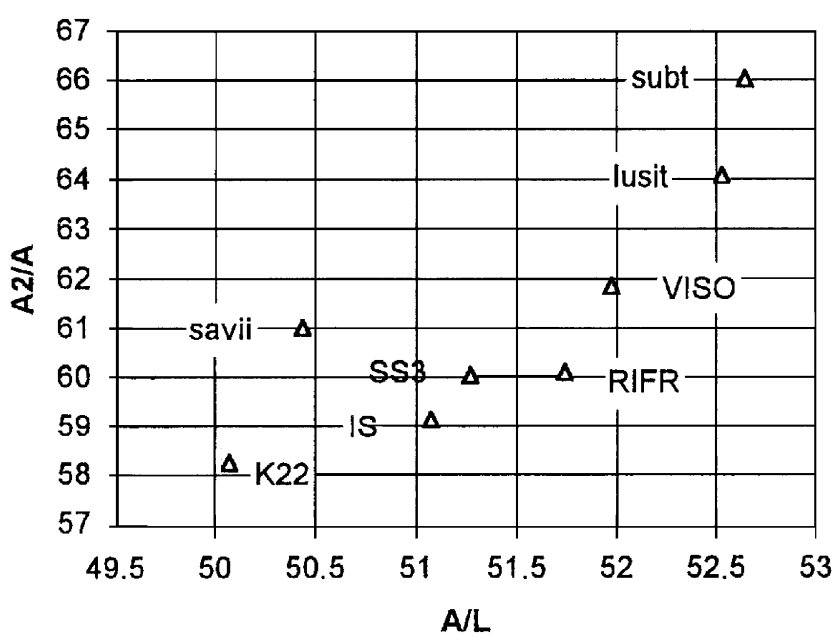

Fig. 9. Scatter diagram displaying mean values of $\mathrm{A} / \mathrm{L}$ vs. A2/A ratios of $\mathrm{M}_{1}$ 's of several M. (Terricola) samples. M. (T.) arvalidens from Rifreddo (RIFR), and Toringian lower levels of Visogliano Shelter (VISO), early Toringian $M$. (T.) multiplex-subterraneus from Isernia (IS), extant $M$. (T.) lusitanicus from Spain (lusit), extant $M$. (T.) subterraneus from France (subt), Eemian $M$. (T.) savii from San Sidero 3 (SS3), Late Glacial from Sicily (K22) and extant $M$. (T.) savii from Apulia (savii). Data from Bonfiglio et al. (1997) except Visogliano and Isernia (this paper).

In conclusion, we assign the sample from Rifreddo to M. (Iberomys) ex gr. huescarensis-brecciensis, whilst taking into account that the sample is too small for observing morphotype variability.

$M$. (Iberomys) was widespread in the Mediterranean regions of western Europe (mainly Spain, southern

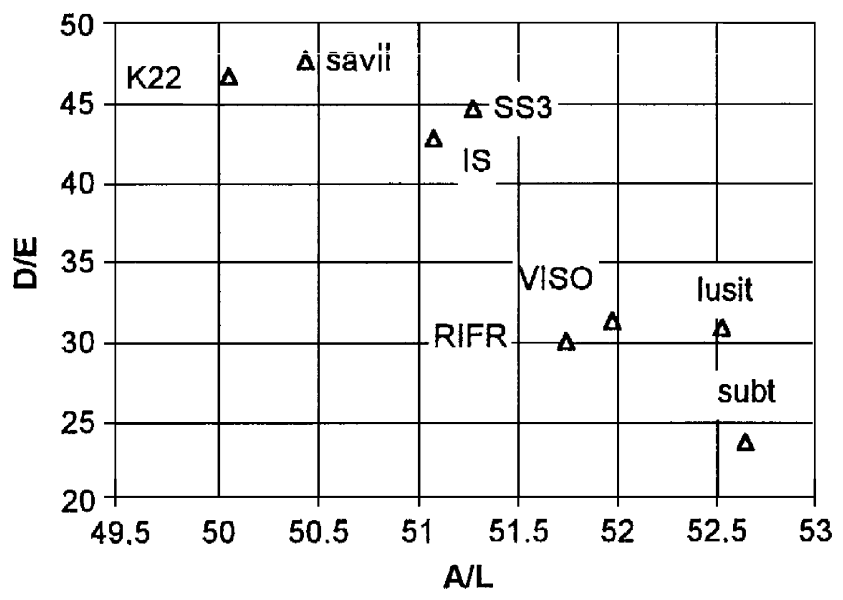

Fig. 10. Scatter diagram displaying mean values of $\mathrm{A} / \mathrm{L}$ vs. $\mathrm{D} / \mathrm{E}$ ratios of $\mathrm{M}_{1}$ 's of several $M$. (Terricola) samples. $M$. (T.) arvalidens from Rifreddo (RIFR), and Toringian lower levels of Visogliano Shelter (VISO), early Toringian $M$. (T.) multiplex-subterraneus from Isernia (IS), extant $M$. (T.) lusitanicus from Spain (lusit), extant $M$. (T.) subterraneus from France (subt), Eemian $M$. (T.) savii from San Sidero 3 (SS3), Late Glacial from Sicily (K22) and extant M. (T.) savii from Apulia (savii). Data from Bonfiglio et al. (1997) except Visogliano and Isernia (this paper).

France and Italy) in the Middle Pleistocene, but is currently restricted to the Iberian Peninsula. Its first occurrence is in the late part of the Early Pleistocene at Atapuerca TD5-TD6 with $M$. (I.) huescarensis, a rather widespread species during the early Middle Pleistocene of Spain (Cuenca-Bescos et al., 1995, 1999).

In Italy, the record of $M$. (Iberomys) is discontinuous: the oldest occurrence of $M$. (I.) brecciensis mediterraneus is at Isernia La Pineta (Sala, 1996); a large sample of this form also occurs at Valdemino (Gliozzi et al., 1997). During the late part of the Middle Pleistocene, $M$. (Iberomys) has a scattered occurrence in the Italian peninsula (e.g. Melpignano, Apulia, M. Rossi, personal communication). The Rifreddo remains represent the record of the oldest and most primitive $M$. (Iberomys) from Italy.

Microtus sp. Fig. 6(16).

Material: 1 right $\mathrm{M}^{3}$

This upper third Microtus molar is not referable to any of the above-mentioned species because of its simple morphology. However, its occlusal length $(1.75 \mathrm{~mm})$, the type of enamel differentiation and the lack of roots allow a

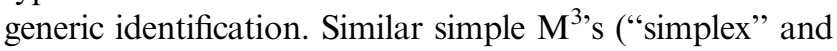
protoeconomus morphotypes) are recorded in several Ukrainian localities such as Microtus protoeconomus from Karaj Dubina and Microtus gregaloides from Protopopovka (Rekovets and Nadachowski, 1995), in Microtus thenii from Podumci (Malez and Rabeder, 1984) and from Untermassfeld, and in Microtus sp. from Süssenborn (Maul, 1990b). 


\section{Discussion and conclusions}

\subsection{Palaeoecological remarks}

Some basic ecological indications can be drawn from the herpetofauna. The presence of Amphibians testify per se to the existence of a body of water. In the case of the Rifreddo site, the presence of permanent water is indicated by a single vertebra of an undetermined fish. We can presume that the three recognised amphibian taxa exploited the same water source during the aquatic phases that mark their lives, or alternatively that they utilised some smaller and temporary water bodies nearby. The last possibility is strengthened by the fact that $B$. viridis tends to reproduce in shallow and temporary (or highly fluctuating) standing waters devoid of fishes (Ferri and Bressi, 1999) and that Triturus populations are negatively affected by the presence of fishes during their larval stages (Aronsson and Stenson, 1995).

These considerations broadly agree with the environmental indications derived by sedimentary and stratigraphic observations. The levels rich in carbon and vegetational remains, from which the fossils have been collected, indicate the repeated occurrence of shallow, discontinuous bodies of stagnant water, similar to those occurring close to the shoreline of lakes. Since these horizons overly a predominantly limnic succession, they might correspond to lacustrine low stands that occurred cyclically during the late depositional phase of the S. Lorenzo Cycle.

More general ecological and palaeoclimatological inferences can be drawn from the mammalian assemblage. In this case a major limit on the accuracy of interpretations is the fact that we are dealing almost exclusively with extinct species, whose habitat preferences cannot be defined from actualistic studies.

The occurrence of arvicolids, as well as hamsters, and the absence of glirids are broadly indicative of open local landscapes. Apodemus is a rather opportunistic murid, not indicative of particular climatic landscapes. M. (T.) arvalidens is characterised by a more southern distribution than other 'boreal' Microtus species and is usually considered a marker of interglacials in central European regions (see Cuenca-Bescos et al., 1995, for a discussion). In terms of Italy, the temperate affinity of this species is confirmed by its occurrence in the lower levels of the Visogliano Shelter, which document an interglacial phase on the bases of sedimentological, palynological and faunal data (Maul et al., 1998; Abbazzi et al., 2000). The same climatic and ecological conditions, but even more pronounced, are indicated by the occurrence of $M$. (Iberomys), which is a typical western Mediterranean form.
Further ecological inferences can be drawn from the insectivore assemblage. Nowadays, Talpa romana is an endemic of southern Italian regions; its occurrence is apparently controlled by the presence of "hard", arid soils, typical of some Mediterranean climates and landscapes (Toschi and Lanza, 1965). Crocidurini shrews are usually considered broad indicators of temperate climate, with a tendency towards aridity. Of course, one cannot expect more precise ecological information from the extinct species C. kornfeldi. Sorex has a very flexible ecology, as demonstrated by its broad north-south geographic range; this shrew, however, avoids very arid, warm climatic conditions (see also Reumer, 1985; Rzebik-Kowalska, 1995). Macroneomys is considered a specialised shrew, adapted to a malacophagous diet, as indicated by the exoedaenodont morphology of its teeth, and predisposed to aquatic habitats or, at least to very moist environments like all extant Neomiyni (Reumer, 1984, 1985; Maul and Rzebik-Kowalska, 1998). Its occurrence in the peat sediment of Rifreddo is therefore not surprising. The climatic affinity of this genus is, however, debated: following the same Maul and Rzebik-Kowalska (1998), it seems that in older localities the occurrence of Macroneomys was related to forest conditions, while this shrew apparently becomes more opportunistic and tolerant in younger localities where it is associated with 'steppe' voles and faunas. Although possibly represented by a different species, at Visogliano Macroneomys, is limited to stratigraphic horizons that were deposited under mild, temperate climatic conditions (Abbazzi et al., 2000).

Summarising all of this evidence, the occurrence of microtines M. (Terricola) and M. (Iberomys) and the shrews Crocidura, Macroneomys and Sorex suggests a temperate climate. This may indicate that the upper sediments of the Rifreddo section were probably deposited during an interglacial (or interstadial?) phase of the Middle Pleistocene.

The occurrence of these temperate species, some of which are indicative of open landscapes, could alternatively be explained if this southern part of the Apennine chain represented a refugia for thermophilous species. In such a case, the possibility that the peaty sediments of Rifreddo were deposited during a "cool" climatic phase cannot be ruled out. However, this interpretation needs the support of further data, some of which can be provided by the investigation of different climatic proxies (e.g. pollen and sediment analysis, which are in progress, see also Sabato et al., 2000). Moreover, we must keep in mind that Italian small vertebrate assemblages of the same age are still poorly known and, therefore, our ideas concerning the north-south distribution pattern of taxa, in relation to climatic conditions, are incomplete. 


\subsection{Biochronological remarks}

Biochronological inferences can mostly be drawn from the small mammal fauna.

In terms of the herpetofauna, with the exceptions of the genus Triturus that has been described previously from few Italian localities, all the remaining taxa are relatively common in the Quaternary of Europe (Delfino, 2002) and are of little help in the definition of the biochronological relationships of this site.

The occurrence of Mimomys savini allows the fauna of Rifreddo to be referred to the Biharian, whilst $M$. (T.) arvalidens, Microtus (I.) ex gr. huescarensis-brecciensis and Macroneomys cf. brachygnathus, indicate the late part of this mammal age, the Mimomys savini 'zone' (Fejfar and Heinrich 1990; Maul et al., 1998). Such assemblages are poorly documented from the Italian peninsula. Late Biharian localities are restricted to the north-eastern area of Italy (e.g. Slivia, Ambrosetti et al., 1979; Monte Tenda, Pasa, 1947), and are characterised by the concomitant occurrence of Mimomys savini and Microtus species (namely Microtus (Stenocranius) hinto$n i$ at Slivia, Ambrosetti et al., 1979; Gliozzi et al., 1997; "Microtus ex gr. arvalis", "Terricola aff. subterraneus" at Monte Tenda, Pasa, 1947). Unfortunately, an updated taxonomic revision of the taxa from the latter locality is lacking. The site of Fontignano (Latium), which has a very peculiar composition for the Italian Peninsula (Prolagurus pannonicus and Predicrostonyx sp.) might be chronologically close to Slivia and Monte Tenda (Gliozzi et al., 1997).

While $M .(T$.$) arvalidens has a wide geographical$ range (from Ukraine to Spain), the occurrence of Microtus (Iberomys) at Rifreddo denotes a certain biogeographical affinity between the Italian Peninsula and Western European Mediterranean regions (Spain and southern France). Although richer in arvicolid biodiversity (Pliomys episcopalis, M. (Stenocranius) gregaloides and two endemics such as $M$. (A.) chalinei and $M$. seseae), the assemblages of Atapuerca TD4-TD6 share with Rifreddo the occurrences of Mimomys savini and $M$. (T.) arvalidens, while $M$. (Iberomys) is represented by the more primitive species M. (I.) huescarensis. Other localities with comparable assemblages are Kozi Grzbiet (Poland, with $M$. (T.) arvalidens and $A$. bursae, Nadachowski in Kowalski (ed.), 1989), and Somssich-hegy 2 in Hungary (Jánossy, 1983).

Late Biharian localities for which magnetostratigraphic and/or radiometric data are available have been correlated with late Matuyama (younger than Jaramillo subchrone) and the lower part of Brunes magnetocrones (see also Cuenca-Bescos et al., 1999, for an exhaustive discussion). More precisely, the Brunhes/Matuyama boundary has been recognised within the Atapuerca section, above the negatively magnetised levels
TD4-TD6, representing the last part of Matuyama. Kozi Grzbiet is positively magnetised and has been dated at around 630-560 ka (Nadachowski, 1985, 1990). Other late Biharian localities, which lack Terricola arvalidens and Iberomys but yield 'true' Microtus associated with $M$. savini, again range from the post Jaramillo to the lower part of Brunhes, for example: Únétice (Czech Republic; Koči and Šibrava, 1976) and Mahlis (Central Germany; Fuhrmann et al., 1977) in which the Brunhes/Matuyama transition is recorded; Voigtstedt (Microtus arvalinus and M. savini, Wiegank, 1975; Maul, in press), West Runton (Microtus $\mathrm{cf}$. arvalis and M. savini, van Montfrans, 1971; Stuart, 1981) and Přezletice (Šibrava et al., 1979; Fejfar, 1969) that are characterised by positive magnetisation assigned to the Brunhes.

Taking into account the positive magnetisation of the sediments outcropping at Rifreddo (Sabato et al., 1998, 2000), the chronological attribution of the mammalian assemblage can be restricted to the early Brunhes and therefore to the early middle part of Middle Pleistocene (Fig. 11). In any case it is older than the FAD of Arvicola, which is considered to have been taken place in Central Europe in Karlich $G$ which is correlated with Cromer Interglacial III or beginning of IG IV and therefore either with IOS 13 or 15 (Roebroeks and van Kolfschoten, 1995).

A more precise, but tentative chronological assessment rests on the more subtle characteristics of the mammal fauna. The occurrence of genus Macroneomys confirms that the Rifreddo assemblage is younger than the $\mathrm{B} / \mathrm{M}$ boundary, since the oldest records of this shrew occur at localities which date from the same period as Voigtstedt and Koněprusy (i.e. approximately 0.6 Ma: Maul et al., 1998; Maul and Rzebik-Kowalska, 1998). However, one must bear in mind that Macroneomys is a rather rare fossil, and therefore uncertainties surround the timing of its first occurrence. Further dating assistance is provided by Microtus (I.) ex gr. huescarensis-brecciensis, which has a more derived morphology than $M$. (I.) huescarensis, suggesting an age younger than the TD4-TD6 levels from Atapuerca. On the other hand, the more primitive characters of the Rifreddo Iberomys with respect to $M$. (I.) brecciensis suggest an age slightly earlier than Toringian.

Considering the palaeobiogeographical aspects, one can observe that, as in many other localities of the Italian peninsula, the faunal composition of Rifreddo is rather similar to that of other European regions and, with the exception of Talpa romana, it lacks the important contribution of endemics that are common on the Iberian Peninsula, for instance. However, the occurrence of Iberomys shows an affinity with western Mediterranean regions. Another trait shared by the Rifreddo fauna and other Quaternary assemblages of central and southern Italian peninsula is the absence of 


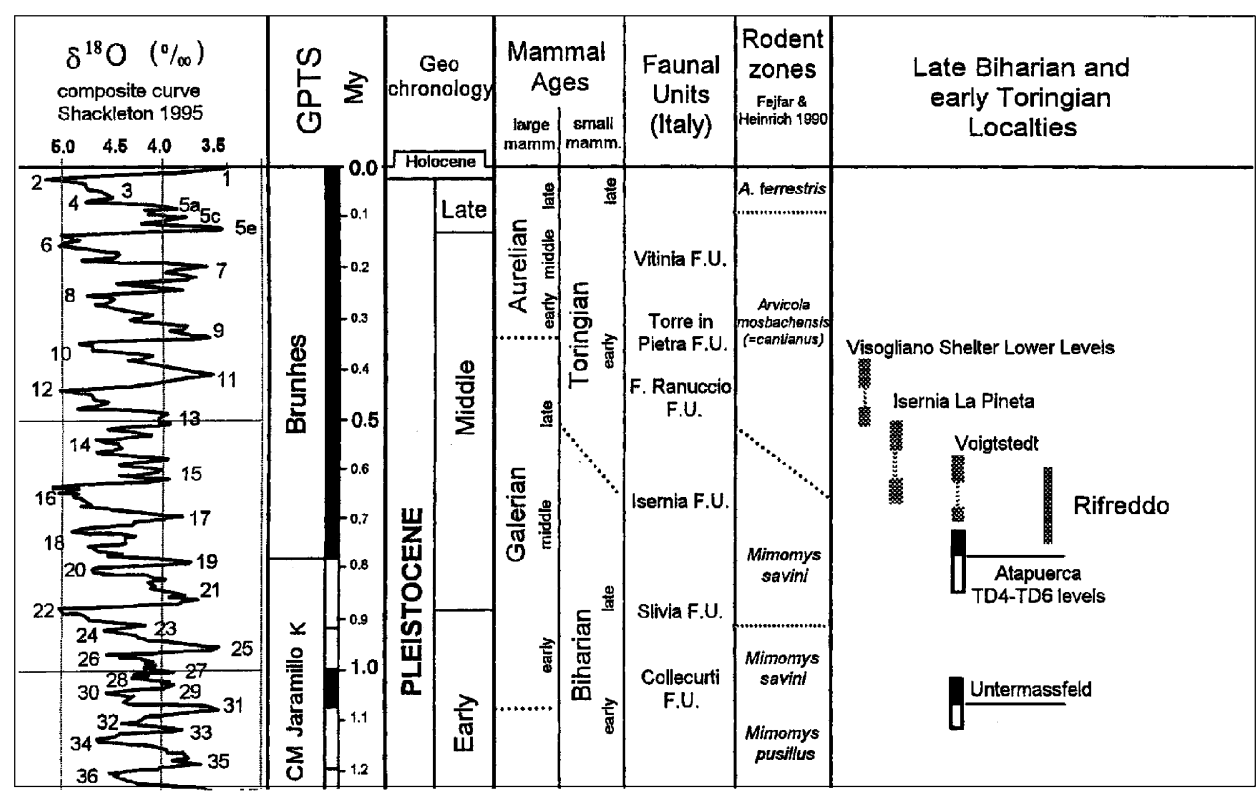

Fig. 11. Chronological scheme showing the possible position of the Rifreddo fauna. Untermassfeld: Mimomys savini and Mimomys pusillus, positive magnetisation referred to Jaramillo; Atapuerca TD4-TD6, Mimomys savini, upper Matuyama, below the B/M boundary, Voigtstedt, Mimomys savini, Brunhes, interglacial phase, Isernia La Pineta, Arvicola mosbachensis (= A. cantianus), with some rooted molars, however, 'cold' climatic phase; Visogliano Shelter lower levels Arvicola mosbachensis (=A. cantianus), interglacial phase.

strictly boreal arvicolids. Even though this feature can be related to the temperate climatic conditions suggested by the ecological requirements of the fauna (see above), several other lines of evidences (for instance see Sala, 1990; Masini and Abbazzi, 1997) show that 'true' boreal taxa are always very rare and apparently appear and disappear from the peninsula as the result of "short" migration cycles controlled by climatic fluctuations (e.g. Coelondonta, Mammuthus primigenius, Sicista, Ochoto$n a)$.

The Rifreddo locality represents an important record of mammal assemblages from the Italian peninsula close to the Brunhes/Matuyama boundary, given that assemblages of latest Biharian age are poorly represented in Italy. Further excavations at the Rifreddo outcrop may yield abundant vertebrate material in a well-defined interdisciplinary framework concerned with the lacustrine succession of S. Lorenzo, in which the transition to the glacial regime is recorded (Sabato et al., 2000). The possibility to develop a detailed integrated stratigraphy by means of palynology, magnetostratigraphy and cyclostratigraphy, combined with radiometric dating control, provides the potential for the precise calibration of the faunal assemblage within Quaternary climatostratigraphy.

\section{Acknowledgements}

We thank Dr. R. Meyrick (Weimar) for critical remarks on the English version of the text and we are deeply grateful to Prof. Gloria Cuenca-Bescos (Zaragoza) for her kind discussion on systematic of Microtus species and for valuable suggestions improving the manuscript. Thanks also to the anonymous referee for his general remarks. Work was supported by Athenaeum grants, University of Palermo (ex 60\%) to. F. Masini and University of Florence to D. Torre (ex $60 \%)$

We wish to thank all the person who contributed substantially during the field survey and sampling: Dr. Annapia Colucci, Dr. Marco Ferretti, Prof. Piero Pieri, Prof. Lorenzo Rook and Prof. Luisa Sabato.

\section{References}

Abbazzi, L., Benvenuti, M., Boschian, G., Dominici, S., Masini, F., Mezzabotta, C., Piccini, L., Rook, L., Valleri, G., Torre, D., 1996. Revision of the Neogene and Pleistocene of the Gargano region (Apulia, Italy). The marine and continental successions and the mammal faunas assemblages in an area between Apricena and Poggio Imperiale (Foggia). Memorie della Società Geologica Italiana 51, 383-402.

Abbazzi, L., Fanfani, F., Ferretti, M.P., Rook, L., Cattani, L., Masini, F., Mallegni, F., Negrino, F., Tozzi, C., 2000. New human remains of Archaic Homo sapiens, and Lower Palaeolithic industries from Visogliano (Duino Aurisina, Trieste, Italy). Journal of Archaeological Science 27, 1173-1186.

Ambrosetti, P., Bartolomei, G., De Giuli, C., Ficcarelli, G., Torre, D., 1979. La breccia ossifera di Slivia (Aurisina-Sistiana) nel Carso di Trieste. Bollettino della Società Paleontologica Italiana 18 (2), 207-220. 
Argenti, P., 1998. La biocronologia dei roditori del Plio-Pleistocene dell'Umbria e l'evoluzione del genere Apodemus (Muridae, Rodentia) in Italia, Doctoral Thesis, Perugia University, $248 \mathrm{pp}$

Aronsson, S., Stenson, J.A.E., 1995. Newt-fish interactions in a small forest lake. Amphibia-Reptilia 16, 177-184.

Bartolomei, G., 1966. Diagramma microfaunistico di Sicista della Grotta della Ferrovia nella "Gola della Rossa" del fiume Esino presso Iesi (Ancona). Annali Università di Ferrara, Nuova Serie 9 (4), 69-75.

Bartolomei, G., 1969. La breccia ossifera di Bosco Chiesanova nei Monti Lessini (Verona): i depositi e la fauna. Memorie Museo Civico di Storia Naturale di Verona 17, 475-494.

Bartolomei, G., 1976. Breccia ossifera a elefante e micromammiferi presso S. Giovanni di Duino nel Carso di Trieste. Accademia Nazionale dei Lincei Rendiconti Classe Scienze Fisiche e Naturali, Serv. VIII 61 (3-4), 274-279.

Bonfiglio, L., Insacco, G., Marra, A.C., Masini, F., 1997. Large and small mammals, amphibians and reptiles from a new fissure filling deposit of the Hyblean Plateau (South Eastern Sicily). Bollettino della Società Paleontologica Italiana 36 (1-2), 97-122 Modena.

Brunet-Lecomte, P., 1988. Les campagnols souterrains (Terricola, Arvicolidae, Rodentia) actuels et fossiles d'Europe Occidentale. Ph.D. dissertation, Université de Bourgogne, pp. 1-146.

Brunet-Lecomte, P., Chaline, J., 1990. Relations phylogénétiques et évolution des campagnols souterrains d'Europe (Terricola, Arvicolidae, Rodentia). Compte Rendue Academie Sciences Paris 311 (Sér II), 745-750.

Caggianelli, A., Dellino, P., Sabato, L., 1992. Depositi lacustri intrapleistocenici con intercalazioni vulcanoclastiche (Bacino di Sant'Arcangelo, Basilicata). Il Quaternario 5 (1), 123-132.

Chaline, J., 1972. Les rongeurs du Pléistocène Moyen et Supérieur de France (Systèmatique-Biostratigraphie-Paléoclimatologie). Cahiers de Paléontologie, CNRS, 410pp.

Clot, A., Chaline,, J., Jammot, D., Mourier-Chauvire, C., Rage, J.C., 1976. Les poches ossifères du Pléistocene moyen et inférieur de Mountoussé (Hautes-Pyrénées). Bulletin Societe Historie Naturalle de Toulouse 112 (1-2), 146-161.

Cuenca-Bescos, G., Canudo, J.I., Laplana, C., 1995. Los arvicolidos (Rodentia, Mammalia) de los Niveles inferiores de Gran Dolina (Pleistocene Inferior, Atapuerca, Espana). Revista Espanola de Paleontologia 10 (2), 202-218.

Cuenca-Bescos, G., Canudo, J.I., Laplana, C., 1999. Biochronological implications of the Arvicolidae (Rodentia, Mammalia) from the Lower Pleistocene hominid-bearing level of Trinchera Dolina 6 (TD6, Atapuerca, Spain). Journal of Human Evolution 37, 353-373.

De Giuli, C., Torre, D., 1984. A microfauna with Allophaiomys pliocaenicus from Gargano (Southern Italy). Palaeontographia Italica 73 (n. ser. 43), 116-128.

De Giuli, C., Masini, F., Torre, D., 1987. The latest Villafranchian faunas of Italy: the Pirro Nord fauna (Apricena, Gargano). Paleontographia Italica 74, 51-62.

Delfino, M., 2002. Erpetofaune italiane del Neogene e Quaternario. Doctoral Thesis, Modena and Reggio-Emilia University.

Fanfani, F., 1998. Macroneomys sp. (Soricidae, Mammalia) from Visogliano Shelter (Trieste, Northern Italy) a site of Middle Pleistocene man. Acta Zoologica Cracoviensia 41 (1), $125-132$.

Fanfani, F., 1999. Revisione degli Insettivori tardo Neogenici e Quaternari della penisola italiana. Unpublished Doctoral Thesis, University of Modena and Reggio Emilia, 282pp.

Fejfar, O., 1966. Über zwei neue Säugetiere aus dem Altpleistozän von Böhmen. N. Jb. Geol. Paläont., Mh 11, 680-691.

Fejfar, O., 1969. Human remains from the Early Pleistocene in Czechoslovakia. Current Anthropology 10 (2/3), 170-173.
Fejfar, O., Heinrich, W.D., 1990. Muroid rodent biochronology of the Neogene and Quaternary in Europe. In: Lindsay, E.H., Fahlbush, V., Mein, P. (Eds.), European Neogene Mammal Chronology. Plenum Press, NY, London, pp. 91-116.

Ferri, V., Bressi, N., 1999. Interventi di conservazione su Bufo viridis. Rivista Idrobiologica 38, 301-310.

Fondi, R., 1972. Fauna cromeriana della Montagnola Senese. Palaeontographia Italica, Nuova Serie 36, 1-77.

Fuhrmann, R., Heinrich, W.-D., Mai, D.H., Wiegank, F., 1977. Untersuchungen am präelsterkaltzeitlichhen Löß von Mahlis (Bezirk Leipzig). Zeitschrift fuer Geologische Wissenschaften 5 (6), 717-743.

Gliozzi, E., Abbazzi, L., Argenti, P., Azzaroli, A., Caloi, L., Capasso Barbato, L., di Stefano, G., Esu, D., Ficcarelli, G., Girotti, O., Kotsakis, T., Masini, F., Mazza, P., Mezzabotta, C., Palombo, M.R., Petronio, C., Rook, L., Sala, B., Sardella, R., Zanalda, E., Torre, D., 1997. Biochronology of selected mammals, molluscs and ostracods from the Middle Pliocene to the Late Pleistocene in Italy. The state of the art. Rivista Italiana di Paleontologia e Stratigrafia 103 (3), 369-388.

Heller, F., 1958. Eine neue altquartäre Wirbeltierfauna von Erpfingen (Schwäbische Alb). Neues Jahrbuch für Geologie und Paläontologie 107, 1-102.

Jammot, T.D., 1973. Les insectivores (Mammalia) du gisement Pléistocène moyen des abimes de La Fage à Noailles (Corrèze). Nouvelles Archives du Musée d'Histoire naturelle, Lyon 11, 41-51.

Jánossy, D., 1969. Stratigraphische Auswertung der europäischen mittelpleistozänen Wirbeltierfaunen. Teil II. Berichte der deutschen Gesellschaft für geologische Wissenschaften, Reihe A, Geologie Paläontologie 14 (5), 573-643.

Jánossy, D., 1983. Lemming-remain from the Older Pleistocene of Southern Hungary (Villány, Somssich-hegy 2). Fragmenta Mineralogica et Palaeontologica 11, 55-60.

Koči, A., Šibrava, V., 1976. The Brunhes-Matuyama boundary at central European localities. In: Easterbrook, J., Šibrava, V. (Eds.), IUGS-UNESCO, International Geological Corr. Progr., Project $73 / 1 / 24$, Quaternary Glaciations in the Northern Hemisphere, Rep. No. 3, pp. 135-160.

von Koenigswald, W., van Kolfschoten, T., 1996. The Mimomys-Arvicola boundary and the enamel thickness quotinet (SDQ) of Arvicola as stratigraphic markers in the Middle Pleistocene. In: Turner, C. (Ed.), The Early Middle Pleistocene in Europe, pp. 211-226.

Kowalski, K. (Ed.), 1989. History and Evolution of the Terrestrial Fauna of Poland. Folia Quaternaria 59-60, 1-278.

Lippi, P., 1997. I micromammiferi del Pleistocene inferiore di Cava Pirro, Unpublished Dissertation in Geological Sciences, Florence University, vol. 1, 187pp.

Mais, K., Rabeder, G., 1984. Das grobe Höhlensystem im Pfaffenberg bei bad Deutsh-Altenburg (Niederösterreich) und seine fossilen Faunen. Die Höle 35, 213-230.

Malez, M., Rabeder, G., 1984. Neues Fundmaterial von Kleinsäugern aus der altpleistozänen Spaltenfüllung Podumci 1 in Norddalmatien (Kroatien, Jugoslawien). Beitrage zur Paläontologie von Österreich 11, 439-510.

Marchetti, M., Parolin, K., Sala, B., 1999. The Biharian fauna from Monte La Mesa (Verona, northeastern Italy). Acta Zoologica Cracoviensia 43 (1), 79-105.

Martin, R.A., 1995. A new Middle Pleistocene species of Microtus (Pedomys) from the southern United States, with comments on the taxonomy and early evolution of Pedomys and Pitymys in North America. Journal of Vertebrate Paleontology 15 (1), 171-186.

Masini, F., Abbazzi, L., 1997. L'associazione a mammiferi della Grotta di Castelcivita. In: Gambassini, P. (Ed.), Il Paleolitico di Castelcivita. Materiae 5. Musei Provinciali Salernitani, Electa Editions, pp. 33-59. 
Masini, F., Santini, G., 1991. Microtus (Allophaiomys) from Cava Pirro (Apricena, Gargano) and other Italian localities. Bollettino della Società Paleontologica Italiana 30, 355-380.

Masini, F., Abbazzi, L., Lippi, P., Sala, B., Torre, D., 1998. Review and new finds of Microtus (Allophaiomys) (Rodentia, Arvicolidae) from the early Pleistocene of the Italian Peninsula. Paludicola 2 (1), 78-90.

Maul, L., (in press). Die Kleinsäugerreste (Insectivora, Lagomorpha, Rodentia) aus dem Unterpleistozän von Untermaßfeld. In: Kahlke, R.-D. (Ed.), Das Pleistozän von Untermassfeld bei Meiningen (Thüringen) Teil 3. Monogr. Röm.-German. Zentralmus, Vol. 40, No. 3.

Maul, L., 1990a. Überblick über die unterpleistozänen Kleinsäugerfaunen Europas. Quartärpaläontologie 8, 153-192 Berlin.

Maul, L., 1990b. Biharische Kleinsaugerfunde von Untermassfeld, Voigtstedt und Sussenborn und ihre chronologische Stellung im Rahmen der biharischen Micromammalian-Faunen Europas. PhD Thesis, University of Berlin, Berlin, Germany, 138pp.

Maul, L., Rzebik-Kowalska, B., 1998. A record of Macroneomys brachygnathus Fejfar, 1966 (Mammalia, Insectivora, Soricidae) in the early Middle Pleistocene (late Biharian) locality of Voigtstedt (Germany) and the history of the genus Macroneomys. Acta Zoologica Cracoviensia 41 (1), 79-100.

Maul, L., Masini, F., Abbazzi, L., Turner, A., 1998. The use of different morphometric data for absolute age calibration of some South and Middle European arvicolid population. Palaeontographia Italica $85,111-151$.

van der Meulen, A., 1973. Middle Pleistocene small mammals from the Monte Peglia (Orvieto, Italy) with special reference to the phylogeny of Microtus (Arvicolidae, Rodentia). Quaternaria 16, $1-144$.

van Montfrans, H.M., 1971. Paleomagnetic Dating in the North Sea Basin. Earth Planet Sciences Letters 11, 226-235.

Nadachowski, A., 1985. Biharian voles (Arvicolidae, Rodentia, Mammalia) from Kozi Grzbiet (Central Poland). Acta Zoologica Cracoviensia 29, 13-28.

Nadachowski, A., 1990. Lower Pleistocene rodents of Biharian voles Poland: faunal succession and biostratigraphy. Quartärpaläontologie 8, 215-223.

Pasa, A., 1947. I mammiferi di alcune antiche brecce veronesi. Memorie Museo Civico di Storia Naturale di Verona 1, 1-111.

Pasquier, L., 1974. Dinamique evolutive d'un sous-genre de Muridae, Apodemus (Sylvaemus). Etudie biometrique des caractères dentarires de popolation fossiles et actuelles d'Europe occidentale. Doctoral Thesis, Academie de Montpellier 183pp.

Pieri, P., Sabato, L., Marino, M., 1996. The Plio-Pleistocene piggyback Sant'Arcangelo Basin: tectonic and sedimentary evolution. Notes et Memoire du Service Geologique du Maroc 387, 195-208.

Rabeder, G., 1981. Die Arvicoliden (Rodentia, Mammalia) aus dem Pliozän und dem älteren Pleistozän von Niederösterreich. Beiträge zur Paläontologie von Österreich 8, 1-373.

Rekovets, L., Nadachowski, A., 1995. Pleistocene voles (Arvicolidae) of the Ukraine. Paleontologia i Evolució. 28-29, 145-245.

Reumer, W.F.J., 1984. Plio-Pleistocene Soricidae from Tegelen and Hungary. Scripta Geologica 73, 1-173.

Reumer, W.F.J., 1985. The paleoecology of Soricidae (Insectivora, Mammalia) and its application to the debate on the Plio-Pleistocene boundary. Revue de Paleobiologie 4 (2), 211-214.
Roebroeks, W., van Kolfschoten, T., 1995. The earliest occupation of Europe: a reappriasal of artefactual and chronological evidence. Analecta Praehistorica Leidensia 27, 297-317.

Ruggieri, G., Rio, D., Sprovieri, R., 1984. Remarks on the chronostratigraphic classification of lower Pleistocene. Bollettino della Società Geologica Italiana 103, 251-259.

Rzebik-Kowalska, B., 1991. Pliocene and Pleistocene Insectivora (Mammalia) of Poland, VIII Soricidae: Sorex Linnaeus 1758, Neomys Kaup, 1829, Macroneomys Fejfar, 1966, Paenelimnoecus Baudelot, 1972 and Soricidae indeterminata. Acta Zoologica Cracoviensia 34 (2), 323-424.

Rzebik-Kowalska, B., 1995. Climate and history of European shrews (family Soricidae). Acta Zoologica Cracoviensia 38, 95-107.

Rzebik-Kowalska, B., 1998. Fossil history of shrews in Europe. In: Wójcik, J.M., Wolsan, M. (Eds.), Evolution of Shrews, Mammal Research Institute Polish Academy of Sciences, pp. 23-93.

Rzebik-Kowalska, B., 2000. Insectivora (Mammalia) from the Early and early Middle Pleistocene of Betfia in Romania, I. Soricidae (Fischer von Waldheim, 1817). Acta Zoologica Cracoviensia 43 (1-2), 1-53.

Sabato, L., 1998. Sedimentary and tectonic evolution of a Lower-middle Pleistocene lacustrine system in the Sant'Arcangelo Piggyback Basin (Southern Italy). Geologica Romana 32, 137-145.

Sabato, L., Bertini, A., Masini, F., Albianelli, A., Napoleone, G., 1998. A lower-middle Pleistocene lacustrine sequence in the Sant'Arcangelo Piggy Back Basin. 15th International Sedimentological Congress, Alicante. Abstract Volume, pp. 687-688.

Sabato, L., Bertini, A., Masini, F., Albianelli, A., Napoleone, G., Pieri, P., 2000. A lower-middle Pleistocene lacustrine sequence in the Sant'Arcangelo piggyback basin (southern Italy). Quaternary International, this volume.

Sala, B., 1990. Loess fauna in deposits of shelters and caves in the Veneto region and examples in other regions of Italy. In: Cremaschi, M. (Ed.), The Loess in Northern and Central Italy, pp. 139-149.

Sala, B., 1996. Gli animali del Giacimento di Isernia La Pineta. In: Peretto, C. (a cura di), I reperti paleontologici del Giacimento Paleolitico di Isernia La Pineta. L'uomo e l'ambiente. Cosmo Iannone ed., pp. 25-49.

Šibrava, V., Absolon, A., Bucha, V., Fejfar, O., Fridrich, J., Horáček, I., Horáček, J., Jánossy, D., Kneblová-Vodičková, V., Kovanda, J., Králík, F., Kysela, B., Nemec, J., Obrhelová, N., Rùžičková, E., Smolíková, L., Vlček, E., 1979. Erforschung der Pleistozänablagerungen auf dem Hügel Zlaty Kopec bei Přezletice (NO-Rand von Prag). Teil I. Antropozoikum 12, 57-146.

Stuart, A.J., 1981. A comparison of the Middle Pleistocene Mammal Faunas of Voigtstedt (Thuringia, GDR) and West Runton (Norfolk, England). Quartärpaläontologie 4, 155-163.

Szyndlar, Z., 1991. A review of Neogene and Quaternary snakes of Central and Eastern Europe. Part I: Scolecophidia, Boidae, Colubrinae. Estudios Geologicos 47, 103-126.

Toschi, A., Lanza, B., 1965. Fauna d'Italia, vol. IV, VII. Calderini, Bologna.

Wiegank, F., 1975. Erste Ergebnisse paläomagnetischer Untersuchungen quartärer Lockersedimente in der DDR. Zeitschrift für geologische Wissenschaften 3 (8), 1103-1109. 